

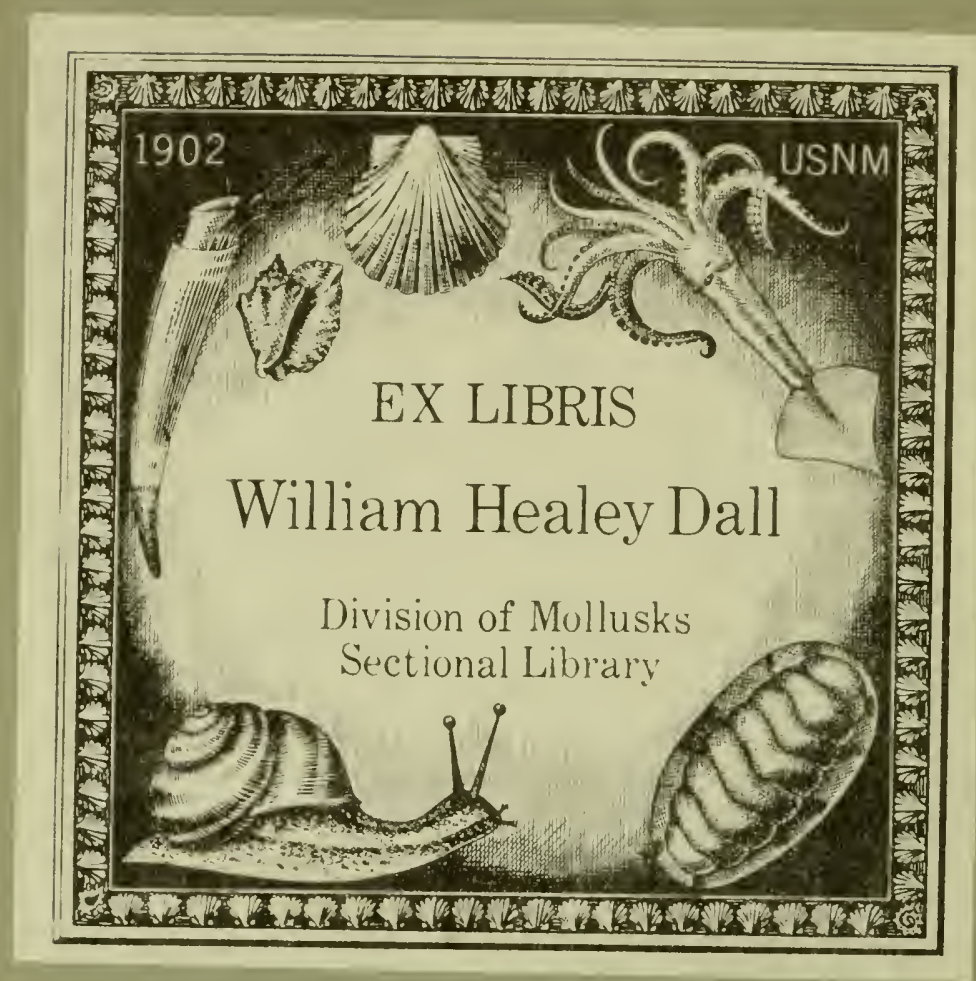




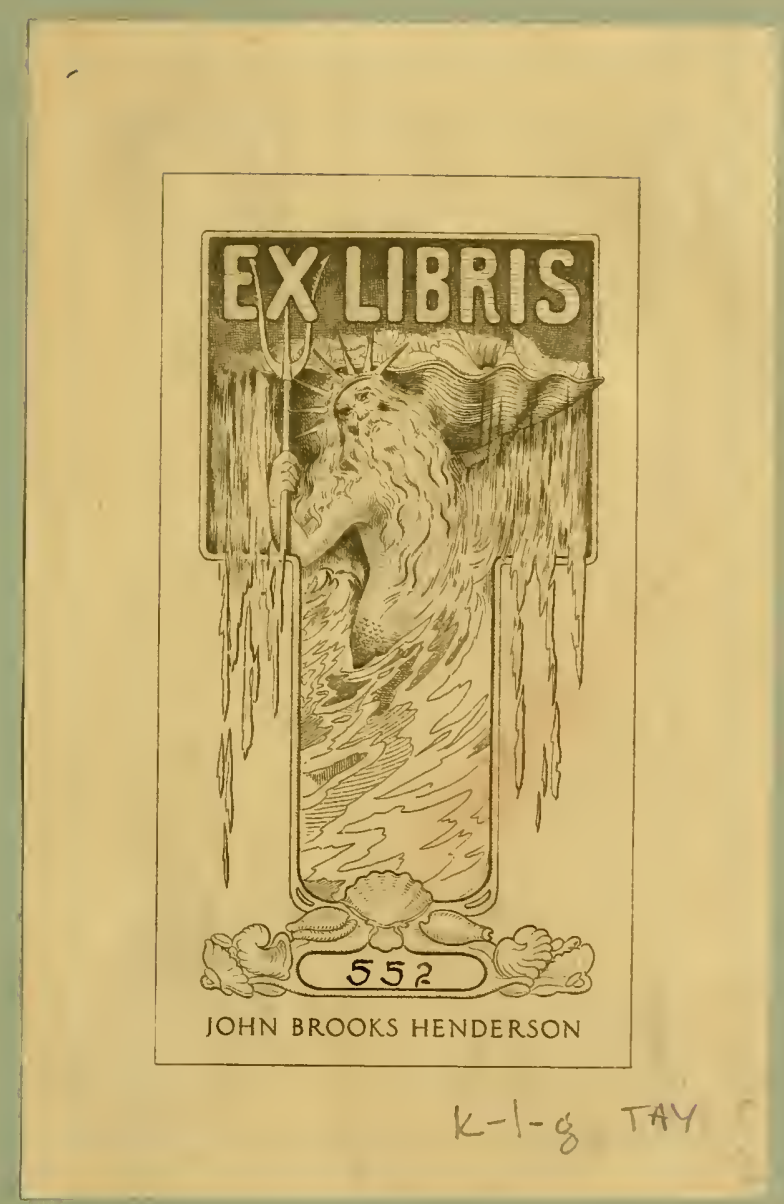






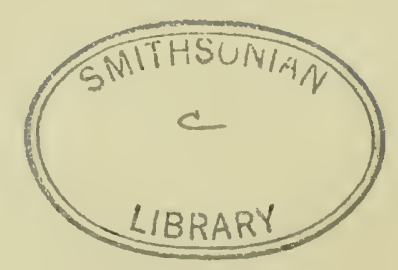


II.-Preliminary Catalogue of the Marine Mollusen of the Paritir. C'nast of Canada, with notes upon their distribution.

\section{By the Reverent Georae W. Tay tor. F.Z.S. Divtsion of Molluebs (Read May 25, 189.)

In the present paper I have not attempted anything move than is expressed in the title, namely a "Preliminary Catalogue" of the Marine Molluscal of onl province.

The time when it will be possible to write an exhaustive history of our western shells has not yet come. Too little local collecting has been done. We who are resident within the province, and who have oppoltunity of examining the shells themselves, are unable to consult much of the necessary literature. On the other hand, naturalists more fiavourably situated with regard to books, and who have access to the great libraries, lack the andrantage of possession of complete series of specimens.

Some day, let us hope, scientific literature will be more accessible to us in the far west and then perhaps we may be able to sudy our fiuna thoronghly on the spot. In the meantime it is beliered that a catalogue like the present, in which are brought together the results of the observations of the principal previous workers, will be of use to those who may, in the future, be led to take up the subject.

It is not claimed, of courie, that even as a compilation this catalogue is free from error, but erery care has been taken in rerifying quotations and records, and it is hoped that no very serious blunders will have erept in.

A writer 11 pon west American molluscal nutst almost of necessity take as his starting point the chassic works of Dr. P. P. Carpenter.

When that distinguished conchologist presented his first report ${ }^{2}$ to the British Association, hardly anything was known of the mollusea of the Vanconver province. Only about 85 species helonging to our tauna were noted as west American in that report, and nearly all of these were either Arctic or Southeru Californian shells.

In the interval, hwerer, between 1856 and the completion, in 1863. of 1 a. Carpenter second report ${ }^{2}$ al vast amount of additional intormation was accumulated.

1 "Report on the present state of our knowledge with regard to the mollnnca of the vest coast of North Amorica," in the Report of the British Asisociation for 1.5ti. published in 1857.

2 "Supplementary report on the present state of our knowledge with regard to the mollusea of the west coast of North Ameriea," in the Report of the Briti-h Assoziation for 1823, publisher in Angust, 1864. 
The naturalists attached to the British and United States Boundary (C)mmissious made large collections of marine shells in Puget Sound and on the shores of Vancouver Island.

Fourteon species, supposed to be new to seience, were obtained by Mr. I K. Lord, of the British expedition, and were deseribed in the Proceedings of the Zoological Society of London (for 1863) by Dr. W. Baird. who at the same time, and in the same publication, described two other species Leda fossa and Nucula Lyalli which had been dredged in Esquimalt Harbour by Dr. Lyall, of H. M. S. Plumper.

The shells collected by Dr. Kennerley, naturalist to the American Commission, were not described mutil two years later, the delay being in great part due to the death of Inr. Kennerley almost immediately atter his return from the expedition. Dr. Kennerley's shells were (o)lected principally in l'uget Sound, and are catalogued, and the new species indicated by I)r. Carpenter in his seeond report. The new species, some 25 in number, were fully described in the Proceedings of the Academy of Natural Sciences (Philadelphia) for 1865. More than seventy species were added to the Vancouver fauna from this collection.

A third very important collection from our waters, examined by 1)r. Carpenter and fully reported on by him in the "Supplementary Report" above referred to. was made by Mr. (now judge) J. G. Swan with the help of Indians at Neeah Bay, and other points on Puget Sound, and the neighbouring British Columbian eoasts. From this collection about 50 speeies not noticed by either Lord or Kennerley were added to our list, about 20 of these being new to seience.

The species contained in these three collections are arranged in systematic order in columns 5, 6 and 7 of the table of species appearing on pages 636 to 664 of Carpenter's 1863 report, and form the "Vancouver" list of thirty year's ago.

The number of species named in this list is as follows:

In colnmm 6. Lord's collection, number of names........ 7 !)

Deduct varieties, etc....................

In column 5. Kennerley's collection, additional names.... sl

Deduct varieties, synonyms, etc............. \&

In columu 7. Swan's collection, additions.......... 7

Less varieties and synonyms... . . . . . . . .

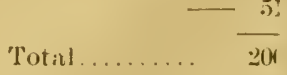

1). Calpenter also quotes from Vancourer Island on other : ittw:ity the following species: Glycimeris generosa, Chrysodomus lira i id Ischnochiton interstinctus, thus raising the total to 203. 
Many of these species were only kuown, in Carpenter's time, from Puget Sound (that is to say United States) localities, but as neally all of them have already heen found to occur in British Columbian waters also, we take it for granter that the others will all eventually be foumd within our limits.

In the present paper 284 marine specios are noted as follows:

In Carpenter's

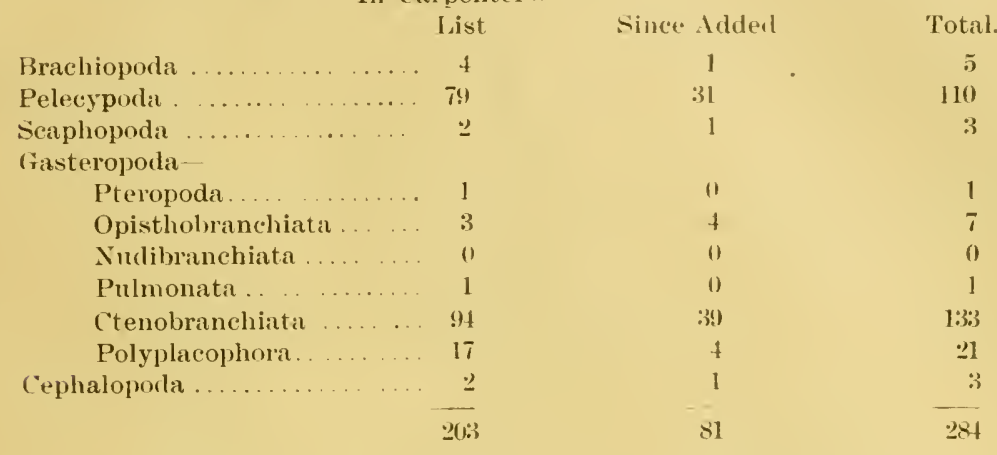

If we add our 67 land and fresh water species we have a total of 351 as being the number of British Columbian mollusea at present known.

Of the 81 additions to the list since 1864 . more than one-half will he found recorded in the four papers, by Mr. J. F. Whiteares, which must now be considered.

The tirst of these is an account of a collection made by Mr. .T. Richardson of the Geological Surrey of Canada on the east coast of' Vancouver Island in 1874-75. It is entitled "On some Marine Invertebrata from the west coast of North Imerica "and it was published in the 'Canadian Naturalist,' vol. viii.. N. S. No. S, December, 1878.

Eleven species are herein added to our list, one of them "Cardium Richardsoni" being described as new to science. This shell hats. however. turned out to be equivalent to Carpenter's $C$. centifilosum. The other additions are:

Megerlia Jeffreysi, Modiolaria nigra, Serripes Laperousii, Kennerlia grandis, Pholadidea ovoidea, Surcula perversa, Buccinum polare, Trophon tenuisculptus, Trophon muriciformis (= Dallii) and "Margarita Tahlii." This last shell, which I hare seen in the Geological Museum, Ottawa, is a specimen of the Solariella varicosa of Mighels and Adams. but though wrongly identified by Mr. Whiteares, is none the less an addition to our list.

Mr. Whiteaves's second paper is a more elaborate one. It is "On some Mariue Invertebrata from the Queen (harlotte Islands " and forns: an appendix (C) to the report of Dr. G. Mr. Dawson on his txplorations 
in the Queen Charlotte Islands in 1878. The paper is published in the Report of Progress of the Geological Survey of Canala for 1878-79.

Dr. Dawson took home quite a large collection of shells of about 135 species, no fewer than 22 being additions to the list, and 2 of these new to science.

The new species are:-Macoma carlottensis and Lepton rude, and the other additions are:-Bryophila setosa, Crenella decussata, Leda crelata (= acuta) Astarte undata, Cryptodon flexuosus, Lucina filosa (= aeutilineata) Macoma sabulosa (= lata) Bela Trevelyana, Mitromorpha filosa, Mangilia sculpturata, Volutella pyriformis, Chrysodomus Harfordi, Odostomia Sitkensis, Odostomia straminea, Cœcum crebricinctum, Lamellaria Stearnsii, "Fenella" pupoidea, "Fissurella" bimaculata, Tonicella marmorea and Chotopleura Hartwegii.

Some of the shells noted in this paper seem to have been incorrectly determined. A few corrections have been made by $\mathrm{Ml}$. Whiteaves himrelf in subsequent papers as follows :-

\begin{tabular}{|c|c|c|}
\hline $\begin{array}{l}\text { Moera variegata, } \\
\text { Astarte semisulcata. } \\
\text { Leda calata, } \\
\text { Chlorostoma brunneum, } \\
\text { Galerus contortus, }\end{array}$ & $\begin{array}{c}\text { should be } \\
\text { "6 } \\
\text { " } \\
6 \\
\text { " }\end{array}$ & $\begin{array}{l}\text { 11. salmonea. } \\
\text { A. undata. } \\
\text { L. acuta. } \\
\text { P. pulligo. } \\
\text { G. fastigiatus. }\end{array}$ \\
\hline
\end{tabular}

The following additional corrections, to which I think Mr. Whiteaves will assent, are also needed:

Turtonia minuta.-The shell, in the Ottawa Inseum, is al large speeimen of Tellimya tumida.

Cylichna alba.-This is C. attonsa.

Amphissa versicolor.-Merely a small form of $A$. corrugata.

A third paper by the same author was published in the Transactions of this Society (vol. iii., section iv., 1886). It is an account of the Invertebrata obtained by Dr. Dawson, principally by dredging, off the northern and northwestern coasts of Vancourer Island in 1855.

One hundred and forty-seven species of mollusea are noted, fourteen being new to the fauna and two, so it was thought at the time, new to science.

The supposed new species are: Cadulus aberrans which still stands, and Leptochiton punctatus the type of which aplears to be a very pale for'm of Ischnochiton retiporosus.

The other additions to the list are: Pecten Vancouverensis (recorded :Is "Alaskensis"), Limatula subauriculata, Yoldia thracixformis, Bela violacea, Cancellaria circumcincta, Admete viridula (= Conthouyi) Sipho (misprinted Siphon) Terkruzeni, Trophon Stuarti (recorded as orpheus) 
Eulima incurva, Barleeia haliotiphila (recorded as subtenuis) Solariella peramabilis, Lepidopleurus cancellatus and Ommastrephes sagittatus.

A few corrections may be made:

Pecten Alaskensis.-This specimen is the type of $P$. Vancouverensis since described by Mr. Whiteaves as a new spercies.

Cylichnu alba.-Is again recorded, but the specimens, which I have seen, are undoubtelly C. attonsa of Gould.

Leptochiton punctatus. - I pale specimen of Ischnochiton retiporosus.

Barleeia subtenuis.-These are B. haliotiphila. B. subtenuis is southern and a much larger shell.

Trophon orpheus. - These are fine specimens of Trophon Stuarti, a perfectly distinct species which has been placed in the synonymy of T. orpheus by sereral conchologists who have probably not had the opportunity of examining many specimens.

Tu Mr. Whiteaves's fourth paper' he describes and figures Pecten Vancouverensis n. sp., and puts on record two additions to our list.Cumingia Californica. a southern shell, and Emarginula crassa, a rather remarkable discovery, as there is not, I helieve. any other record of the oceurrence of the species in the Pacific Ocenn.

It will be seen that in these four important contrihutions to our knowledge no fewer than torty-nine species are added to Carpenter's list.

The efforts of other collectors during the past few years have resulted in a further addition of 32 names, and there is little donbt but that there are still many more species inhabiting our waters to be one day discovered by the enthusiastic conchologist.

The local collections to which I shall refer in the present paper have been made by I)r. ( . F. Newcombe, Professor Macoun and myself. Dr. Newcombe has collected diligently and successfully in the neighbourhood of Victoria; at Comox, 140 miles north of Victoria; at Clayoquot Somnd on the west coast of Vancouver Island; and in some other localities. The results of his work appear in a "Report on the Marine Shells of British Columbia," which was published in February last in the 'Bulletin of' the Natural History Society of' British Columbia.' This report contains a large amount of information on the distribution of our mollusca and has indeed almost rendered the present paper unnecessaly.

Professor Macoun collected last year (1893) at Comox, Namaimo and Sooke with much snceess. In .July last, I had the pleasure of joining the professor in a clay's dredging in Departure Bay. Using a home-made dredge from an ordinary sailing boat manned by three

1 " Notes on some Marine Invertel)ratil from the coast of British Columbia," Ottawa Naturalist, vol. vii., 110. 9), p. 1:3:3 (Decemher, 18:13). 
inen, we secured more than 7,000 specimens of 88 species of mollusca, including one sprecies, Rictaxis punctocalata, that I had not before observed in this movince.

I had myselt' collected on a previous occasion in the same locality ; and during a number of yoars I have dredged and made shore collections near Victorial and at Vesuvius Bay and Ganges Harbour, on Salt spring Island; and at Comox. I have not so fitr had any opportunity of personally visiting more northern or west coast localities.

In the motes that follow, I have endeavoured to give under each species, a reference to the original description and tigure; secondly, wuch synonyms as appear necessary to connect this list with prerious papers on the same subject, likely to be consulted by the student; thirdly, a list of the localities, within the province, in which the shell has been found; and lastly, some brief notes as to its station, relative abundance, and so forth.

The determination of the shells themselves may be accepted, I think, as fairly accurate. I have had opportunities of studying the large collections in the Museum of the feological Survey in Ottawa, and also the Vancouver shells in the Natural History Museum at South Kensington. Moreover, most of the difficult species have been submitted at different times to Dr. Dall, who has most kindly helped me, during several years past, in identifying puzzling specimens.

In the arrangement of the species I have endeavoured to follow, as nearly as I could, the classitication adopted by Dr. Dall in his most uscful catalogue of the shells of the Atlantic coast of the United States. published in 1889, as Bulletin 37 of the U. S. National Museum.

No attempt has been made to give a complete bibliography of the subject, but the titles of a number of the most useful papers are given in full in the following notes. Other useful papers, to which it is not possible to refer at length here, have been contributed by Drs. Cooper, Dall, Stearns and Pilsbry to the American Journal of C'onchology and the J'roceedings of the Academy of Natural Sciences (Philadelphia) the ralifornia Acarlemy of Sciences and the United States National Museum. 


\section{CATA LOGLE OF SPECINS, WITH NOTES.}

\section{IBIRACHIOPODA.}

The recent Brachioporla, and especially the American species, bave been well worked up by Dr. Dall. To his numerous papers on the subjeet in the American Journal of Conchology (rols. vi. and rii.) and in the Proceedings of the Acatdemy of Natural sciences of Philadelphia, the student is referred for extended notices of onr British Columbian forms. ${ }^{1}$

TEREBRA'TLLINA, D'Orbigny.

\section{1. 'Terebratulina unguicula, Cappenter. sp.}

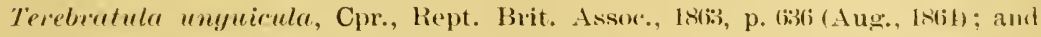
Proc. Zool. Soc. London, 18(i5, p. 201, fig. 1.4.

'This species is now generally considered to be only a ratriety of ' $T$. caput-serpentis, Linne, sp. (Anomia caput-serpentis, Linn., Sỵst. Yat., ed. xii., vol: i., pt. '2, p. 1153, 110. 236,1767 ) which in, of course, the older name. Our species or variety was first described as from "San I Hego 6 fms., Monterey, not rare in 20 fms. (Coper, Neeah Bay (valve) Swan, Vancouver, Forbes." It is not rare at Victoria and Departure Bay and has been dredged by Dr. Dawson in the straits of Georgial, Discovery Passage, Johnston Strait and Forward Bay. Probahly it, will be found to occur throughont the province. Generally specimens are found attached to stones or dead shells dredged in from 1 to 100 fathoms, lut on one occasion I obtained at fine series attached to the hairy epidermis of' a living specimen of Tritonium Oregonense. Dr. Datl states that specimens from deep water are generally larger than those from near low water mark.

'TEREBRATELLA, W'Orbigny.

\section{Terebratella transtersa, Sowerby, sp.}

Terebrutule transiersa, Sby., Proc. Zool. Soc. London, 1stli, p. 94: and Thes, Conch., vol. I., p. 261 , pl. 72.2 , fig. $114-115$ (1846) = Terebrutula carvina, Gould, Proc. Bost. Soc. Nat. Hist., vol. iii., p. :34 (1)ecemuer, 18s̄o) ; and IT. S. Expl. Exped., p. 468. figs. 582-582( (1852).

This is an extremely common shell with us. It occurs in two distinct forms-a smooth deep-water form, which is the typical transversa, and a highly sculptured form occurring in thousands between tides. and

' Descriptions of all our species are contained in Dall's " Report on the Brachiopoda of Alaska and the adjacent shores of Northwest America." Proc. Acarl. Sci. Phil., 1877, p. 155 et sey. 
to which fiomld's name. caurina, more strictly applies. The shore variety sometimes attains a very large size, one mentioned by Dall measuring $58 \times 50 \times 31 \mathrm{~mm}$. I have specimens from sialt spring Istand and

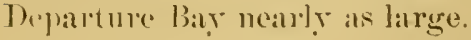

L.AQUEUS. Dall.

3. Laqueus Californicus, linch, sp.

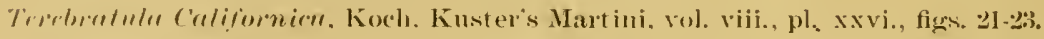

This is not a common shell in any locality. Dall quotes its range as from Port Etches to Catalina Island, California, and remarks that it is (:Terywhere lare, awing to its deep-water habitat. It is sometimes, however, fouml in comparatively shallow water, as at Victoria, where Mr. Richardson, Dr. Newcombe and myself have all dredged it. It has also heen taken within the province by Dr. Dawson, in Discorery Passage and Johnston Strait and at the Queen Charlotte Islands.

British Columbian specimens are said to be smaller than Californian ones. and have received from Dr. Daridson, in his latest work, ${ }^{1}$ the rarietal natme of Vancouverensis.

ItEGERLld, King.

4. Megeria Jefreysi, Mall.

Isumernice (?) Jeffirt!sis, Dall. Amer. Journ. Conth., vol, vii., p. (i5, pl. xi., tig. $\bar{T} 10$ (A:treh, 1871).

The only specimen that I have heard of as having been taken in British columbia is the single deat shell obtained by Mr. J. Richardson at Victoria in 1875.

HEMT'THYRIS. W'Orbigny.

5. Немithyris psittacea, Gimelin, sp.

A momin psifturea, Gmelin, Syst. Nat., ed. xiii., vol. i., pt. vi., p. 3348 (1768).

This is a common and well-known cipcumpolar shell, which on the west Ameriean (oalsts seems to reach its southern limit at the Straits of Fuc:al.

Though not so abundant in British Columbia as 'T. transversa " 1 T. unguicula, it has been met with at Vietoria by Mr. Richardson. Dr. Newcombe and myself. and at Diseovery Passage and lohnston Strait - by Jor. Dawson.

1 "Nonograph of Recent Brachiopoda," Trank. Linn. Soc. London, vol. iv.,

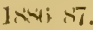


PHIACYPOINA.

OS'TREA. Iinne.

6. OSTREA TLRIHA: ('PR'.

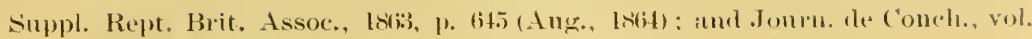
xii., p. $1: 37$ (April, 186.5).

Common on all the coasts of British Columbia, northwarl to Queen Charlotte Sound. Dr. Dawson found specimens at Malaspinal Inlet and also (abundantly) at Bradley Lasgon, Blunden Harbour, Queen Charlotte Sound, on the mainland sicle. This last locality is said by Mr. Whiteares (Trans. Roy. Soc. Can, iv., iv., 118) to be the most northerly locality on record for the species in British Columbia.

7. Ostrea Tirginica, timelin.

Syst. Nat, ed. xiii., vol. i., p. 333366, no. 113 (178s').

This species was introduced into the "Victoria Arm" some years ago, and has become to a certain extent naturalizerl. Prof. Macoun last summer (1893) found a finely grown adult specimen some little distance from the mouth of the Colquitz River. which flows into the Vietoria A rm.

PJARUNA NOMIA, Broderip.

8. Plicunanomia macroschisma, Deshayes, sp.

Amomir macroschisma, Desh., Rev. Zool. Six. (nv., p. 359) (Dec., 18399) : Mage. de Zool. (Guerin's) 184I, pl, xxxir.

Tery common everywhere between tirles, and found also, lout less firequently, in deeper water.

My finest specimens ale from the rocks at Vesuvius Bay, Salt Spring Island. Tery curions forms ocenr in the burrows of Penitella.

PECTEN, Miiller.

\section{Proten caurinus, fionhl.}

Proc, Bost. Soc. Nat. Hist., rol. iii., p. 345 (Dec., 18501) ; and U.S. Expl. Fixped.. Mollusea, p. 458, tig. 569 - 5691) (1852).

Not very common. This species was not found by Dr. Dawson either at the Queen Charlotte [slands of at the north of I ancouver Island.

The specimens I have seen hare nearly all been from the neighbourhood of Comox. where Richardson dredged it in 187t, and where Dr. Newcombe has since taken it. 
I have myself dredged this species living, but only on one occasion, near Victoria.

$$
\text { 10. Pecten hastatus, Sljy. }
$$

Thes. conch., vol. i., p. 72, pl. xx., fig. 223ti, = hericius, (xomld.

('ommon, and in some places'very abundant, on both the east and west coasts of Vancouver Island. Varieties are pink, yellow, and very rarely pure white. This shell is usually dredged in 10 or 20 fathoms, but may sometimes be found living on rocks between tides. On one occasion I dredged, in the course of a few hours, more than tive hundred specimens of this species; this was in the straits about one mile from Victoria.

Many specimens are tound covered with a sponge, Myxitis parasitica, Lambe. 'This sponge when living is of a bright yellow colour, and the Pectens so covered, as they are taken from the dredge, have the appearance of small oranges.

Dr. Dawson found a valve of $P$. hastatus with a specimen of Bivonia compacta attached. I beheve, however, that the Bivonia is more usually found on a gasteropod-Pachypoma iniequale.

\section{Pectex rubible, Hinds.}

Zool. Voy. Sulph., vol. ii., p. 61, pl. xvii., fig. इ) (1stt).

This is usually considered to be a variety of the last species, and perhaps it may be so.

It is not rare near Victoria, occurring with $P$. hastatus, but in this locality it in always readily separable from that species and does not show any intermediate forms. The soulpture is not nearly so rough as in $P$. hastatus, the rilis are equal and more numerous, the shape is rounder, and the colour's duller.

\section{Pecten (Pseudanusium) Vancouverensis, Whiteares.}

Ottawa Naturalist, December, Is:3i, p. 13:3, p]. i., figs. 1, 1 a.

This little shell was tirst found by Dr. Dawson in 1885, in Forward Inlet, Quatsino Sound.

It was recorded by Mr. Whiteares as P. Alaskensis, Dall (see below), hut he bas corrected this error, and described the species as new in his paper ahove cited.

I obtained two specimens of $P$. Vancouverensis in Departure Bay in Augnst, 1888, and these were compared with the Pectens in the British Inseum, through the kindness of Mr. E. A. Smith, and with those in the United States National Museum by Wr. Dall and pronounced distinct. Sonce conchologists, however, have inclined to the riew that this may be 
the young of $P$. caurinus, to which, to the naked aye, it beats rome resemblance.

Last summer, in complany with Prof. Macomn, I dredged a serien of various ages in Departure Bay, and I am satisfied that I have adult shells. The type specimen measures $7.5 \times 7.75 \times 2.25 \mathrm{~mm}$, and is the largest I have seen.

\section{Pecten (Pseunanusium) Alaskinsis, Dall.}

Aner. Jour. Conch., vol. vii., p. 155, pl. xvi., fị. 4 (November, 1871 ).

This species, with which the last named was at first confounded, did formerly inhabit our seas, as is proved by the presence of the fossil shells in a Pleistocene defosit at Point IJolmes, Comox. Valves, collected and kindly given to me by Dr. Newcombe, are in ny cabinet from this locality. The species is probably still living in our northern waters.

$P$. Alaskensis and the fry of $P$. caurinus are figured in one of the valuable and eheap United States Gorernment publications.'

This inexpensire work is within the reach, and should be in the possession, of every American conchologist. The figures alluted to are on plate v., and should be 'ompared with that of $P$. Vancouverensis in the "Ottawa Naturalist."

\section{IIINNITES, Defrance.}

\section{Hinnites giganteles, limy.}

Himnite gigented, Gray, Amm. Phil., vol. xii., p. 103 (Ang... 1אי6).

Not rare, being found in all the localities examined. It oceurs attached to boulders from extreme low water to twenty or more fathoms in depth. Dr. Diwson found it at Queen Charlotte Islands, and in 1885 in several more southerly localities. My largest specimen is $175 \times 138$ mm.. but I have no doubt that these dimensions are often cxceeded.

L1MATLLA, searles-Wood.

\section{Limatula subauriculata, Montag'u. sp.}

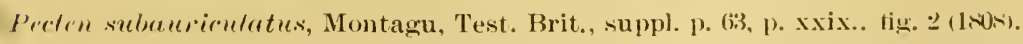

This sprecies rests its claim to a place on our list upom two living specimens dredged by Dr. Dawson in 1885, one in Forward Bay, lohnston Strait, and the other in Alert Bay, Queen Charlotte Sound. Both

1 "Bulletin of the United States National Museum No. 37," entitled " A Prelininary Catalogne of the Shell-bearing Marine Mollusks and Brachiopods of the Southeistern Coast of I'nited States." 
specimens ale in the museum of Geological and Natmmal Hintory Survey at Ottawa. L. subauriculata is a shell of very wide range, occurring ou loth sides of the Atlantic from the extreme north to the Canary Islands on the east and to Florida on the west side of the ocean.

Its range in depth, according to Dr. Dall, is "6 to 843 fathoms." It liak also a considerable range in time, being, acording to Jeffreys, a forsil of the British ('oralline ('ara.

Being rather common in the Californian region, and also to the north of us, it is to be expected that it will be found in other localities oul the Tancouver coasts.

BRYOPHILA. Carpenter.

16. Bryopilla setosa, Cpr.

Amn. Mag. Nat. Hist., series 3, vol. xiii., p. 314 (April, 1ritit).

Described from Cape St. Lucas (Xantus) and recorded also from Calitornian localitics.

Our first British Columbian record is that of Dr. Dawson : "Virago Sound, Queen Charlotte Islands, in 8-15 fathoms, 4 fine living specimens."

I have a single specimen which was picked up on the sands at Alert Bay by Mr. E. S. Wilkinson, and which, from a comparison with one of Mr. Xantus's original lot, I helieve to helong to this sperien.

MYTILES, Lime.

\section{Mythus Californinus, Coniad.}

Juurn. Acad. Nat. Sci. Phila., vol. vii., pt. ㄹ, p. 242, pl. xviii, tig. 15 (1\$3i).

Common between tides and growing to a very large size. It is eaten by the Indians, and in its season is often to be seen on sale in the Victoria tish stores.

18. Mytulus enulis, Lime.

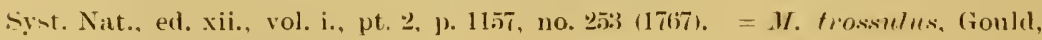
and many otler synonyms.

Everywhere between tides. It is regularly on sale in Victoria, but is not valued as an article of food to anything like the sime extent as in liumpe or castern America.

M. edulis has a very extended range. being found throughout the whole northern hemisphere. ${ }^{1}$

${ }^{1}$ Northern localities for $M$. edulis, and for the following British Columbian species, are given in a "Catalogue of shells from Bering Sen and the adjacent portions of the Arctic Ocean" which was contributed by Dr. Dall, 20 years ago, to the Proceerlings of the Californian Academy of Sciences (vol. 5, p. 2246.2573, 1874): M! thilus 
MODIOLA. Lamarek.

19. Modrola ReCta, Comrad.

Jomm. Acad. Nat. Sci. Phila., vol. vii., pt. 2, p. 243, pl. xix., fig. 1 (143i). Var -Nytilus (Modiolet) Mlabelletus Gould, Proc. Bost. Sor: Nitt. Hist.

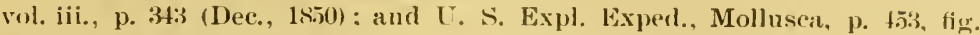
561 and 561:a (185:2).

I tine, large species, attaining sometimes to a length of serent inches. It has not as yet been found commonly in our water's, but perhaps it only needs searching for.

Dr. Newcombe has taken it in Ganges Harbour, Salt Spring Island, and at Clayoquot Sound. I have found it at Victoria, and have received specimens from the west coast of Vancouver Island. According to Carpenter, our local form of this species is the M. flabellata of Gould. which is brouler than the typical $M$. recta of Conrad.

20. MoDiola modiola, Lime, sp.

Mytilus morliolus, linne. Sỵst. Nat., ed. xii., vol. i., pt. 2, p. 1158, no. 25̆6 (1767).

Common everywhere. The deep water forms are much larger than the between tides varieties, attaining a length of five inches. Jeffreys (Brit. (onch., vol. ii., p. 113) records specimens, from the Northumberland coast. measuring $9 \frac{1}{4}$ inches in length and proportionately broad.

ADULA, H. and A. Adams.

21. Adula stylina, Carpenter.

Rept. Brit. Ansoce, 1Niti3, p. 64t (Angust, 1864); and Anm. Mag. Nat. Hist., 3rd series, vol, xiv., p. 425 (Dec., 1864).

Found boring in soft rock between tides; near Victoria. I ford and Newcombe; Sooke Harbour, Professor Macoun.

MOIOIOLARIA, Beck.

2.. Modiolaria lowigata, Gray, sp.

Morlisele lerigutu, Gray, Suppl. to App. to Parry's Second Voyage (1א2t).

Not uncommon in 10 to 30 fathoms, Victoria and Nanaimo. J)r. Dawson found a living specimen associated with Saxicava rugosa, at low

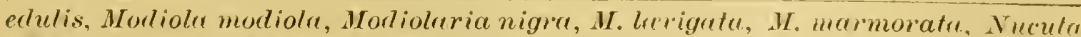

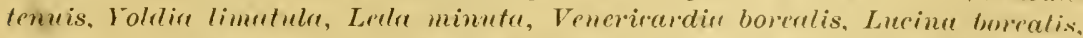
Servipes Airomlandicus, s. Laprousii, Maromen nesutu, M. edentule, M. incon.

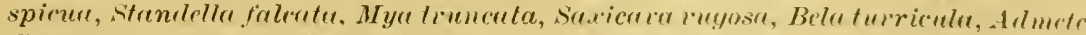
Conthouyi, Buccinum Ioerrhienum, Chrysodomus fornicrelus, C. liretus, Trophon melticostatus, T. orpheus, Purpure lime, Trirhotrophis cuncellate, Mescrlire reticu.

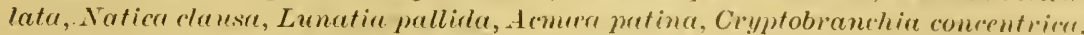
Margerita heliciun, and Tonicrlla lincuta.

Furtler information as to the northern lange of our shells is given in later papers by the same author, reference to which will be found below under, $-\mathrm{Cr}$ !nto

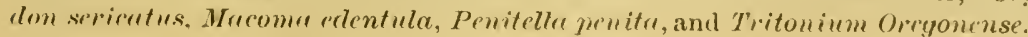


water at Port Neville, near Johnston Strait. This wonld be an musmal station for the species, as it is generally found in deeper water and conpletely encatsed in a "nest" construeted chiefly of its own byssal threads.

\section{IGDIOLARIA NIGRa, Gray, s].}

Modiolu wigre, Gray, Suppl. to App. to Parry's First Voyane, p. 244.

Distribution and station similar to those of $M$. lwvigata, but the present species does not construct a " nest."

\section{Modiolaria Taylori, Dall, MS.}

This species has been found by me abundantly at Victoria, between tides, nestling at the roots of corallines. It is a small species not exceeding half an inch in total length and resembling in habit $M$. discors, Iinne, of British seas.

This species has not been described, but has been widely distributed under Dr. Dall's manuscript name.

25. Modolaria iarmorata, Forbes, sp.

Mytilus mermoratus, Forbes, Maliac. Nonen., p. 44.

Recorded by (arpenter in his "Supplementary Report" as from Puget Sound (Kemnerley, one specimen), with the remark, "Lxactly accords with Atlantic specimens."

I was inclined to think at one time that the last named species might be the one intended, but it is so very different to $I$. marmorata, that 1)r. Carpenter could not have made such a mistakc. Moreover, I find that M. marmorata is on record from several other localities in the Pacific Ocean both to the north and the south of us. It is also found, aceording to Jeffieys, in Japan.

CRENELLA, Brow.

26. Crenella Decussata, Montagu, sp.

Mytitus decussuturs, Mont., 'Test. Brit., suppl. p. 69 (180s).

Common in ten to twenty-five fathoms and probably to greater depths. Our shells are much larger than Atlantic specimens. Mr.

1."On some Species of , apanese Marine Shells and Fishes which inhabit also the North Atlantic," by J. Gwyn . Ietheys in .Jommal of the Linnean Society (Zoology), vol. xii., p. 100 , November, 1874. In this paper Dr. Jeffreys mentions more than forty species of mollusea conmon to Japanese and European waters, and, as might be expected, the majority of these species occur also on the West American coast. several additions to the list have been male by subsequent writers. 
Whiteaves gives the dimensions of a specimen dredged by Dr. Dawson in Alert Bay at $12 \times 11 \times 7.5 \mathrm{~mm}$, and I have a shell slightly larger even than this. ${ }^{1}$

According to Dr. Dall's arrangement, which we are following, the suborder Naiadacea will come in here. We have two species of this order, of course inhabiting fresh water, and belonging to the family Unionide. They are:

\section{Anomonta nuttalliana, Leil.}

28. Margaritana margaritifera, Linne, sp.

IXIN.EA, Poli.

29. Axin.ea septentrionalis, Middendorff, sp.

Pectuncuhus septentrionulis, Midd., Mal. Ross., pt. :ji., p. 67, pl, xxi., fig. 1-3 (1к!9). var. = A. subolssoleta, Cpr., Rept. Brit. Assoc., 1863;, p. 614 (Aug., 1864); and Ann. Mag. Nat. Hist., 3rd series, vol. xir., p. 42:5 (Déc., 1864).

This species does not occur in the neighbourhood of Victorial, so far as I have observed. It is found, however, not uncommonly on the western and northern coasts of Tancouver Island and at the Queen Charlotte Islands. (Dawson.)

Our shell is the $A$. subobsoleta of Curpenter, but its specific identity with the septentrionalis of Middendortf is doubted by some eoncholngists.

NUC'ULA, Lamarck.

30. Nucula castrensis, Hinds.

Proc. Zool. soc. London, 1843, p. 9s; and Zool. Voy. Sulph., rol. ii., p. 633, pl. xriii., tig. $5(1844),=$ N. Lyalli, Baird, Proc. Zool. Soc. London. 1863, p. it

This shell, which is undoubtedly the $N$. Lyalli of Baird, and almost certainly the $N$. castrensis of Hinds, is the commonest bivalve shell occurring in our seas. In Departure Bay last year I dredged more than 2,000 specimens of it in one day. Dr. Dawson dredged it at the Queen Charlote lslands and in many localities to the north of Tancourer Island.

1 Since writing the above I have had oceasion to exanine the description and tigures of the true $C$. recuswrtu of the Atlantic, and I find that onr British Colum. hian shells do not belong to that species at all. Mr. Whiteaves, in his account of Dr. Dawson's collections, has twice recorded onr shells as C. Alecussutu, and as the species had alrealy been found on the Californian coast, I suppose we accepted his determination of the shell without question. On species malse $C$. faba, O. Fab., but unfortunately I cammot at this moment refer to either descriptions or sperime'ns of this specien. 
31. Nucula tentro, Montagu, s].

Arre tenuis, Mont., Test. Bril., Suppl. p. 56. pl. xxix., fig. I (1818).

Qceurs with the last named species. but is not quite so common.

IEDA, Schumacher.

32. Leda fossa, Baird.

Proc. Zool. Soc. London, 1863, p. 71.

This species was described from a single specimen taken by Dr. Iyall in Esquimalt Harbour. It was also represented by a single specimen in Dr. Kennerley's collection.

Though $L$. fossa is very abundant in the "Leda clay" of Victoria, I have never succeeded in finding recent specimens. Mr. Whiteaves records with a query "a single worn valve," Duncan Bay, V. I. (Dr. Dawson.)

33. Leda minuta. Müller, sp.

Arce minute, Müll., Prodr. Zool. Dan., p. ำ7, no. 2985 (1766).

This is the common Leda at Victoria and northward to the Queen Charlotte Islands. It is much smaller than $L$. fossa, and its sculpture is quite different. I have not yet found this species in the Leda clay.

$$
\begin{aligned}
& \text { 34. Leda acuta, Conrad. } \\
& =\text { ? L. crelata, Hinds. } \\
& =\text { ? L. cuneata, Sby. }
\end{aligned}
$$

There is certainly a third species of Leda in our seas, but I am not sure what it should be named. Mr. Whiteares, in his paper on the Queen Charlotte Islands Mollusca, recorls a single valve from HoustonStewart Chamel as $L$. colata, IIinds.

In his next paper (Trans. Roy. Soc. Can., 1886) he refers ten shells of the same species from Quatsino Sound to $L$. acuta, but suggests, quoting Drs. Dall and C'ooper, that acuta, Conrad, coelata, Hinds, and cuneata, Sby, are one and the same species. I have not access to the literature or specimens necessary to a decision on such a point, and therefore follow Whiteares in adopting the name $L$. acuta, but I may nay that the shells from Quatsino Sound above mentioned are not conspecific, in my opinion, with some received as $L$. acuta from Californial (Hemphill).

JOLDIA, Möller.

35. Yoldra thraclakoriss. Storer, sp.

Nuculu thrarinformis, Storer, Bost. Jour. Nat. Hist., vol. ii., no. 1, p. 122, tigure (183\$).

Two small living specimens, Forward Inlet, Quatsino Sound, I)r. Jawson. 
I do not know of any other reeord of the occurrence of this eastern American species on the Pacific coast.

36. Yoldia lanceolata, J. Sowerby, sp,

Nucula lancelata, J. Sby., Mineral Conchology,

Fairly common at Victoria, Nanaimo, etc., and occurring also at the Queen Charlotte Islands and in Quatsino Sound (Dawson).

The "very large" specimens recorded from Comox by 7 r. Newcombe should probably be referred to the next species.

37. Toldia seminuda, Dall.

Amer. Journ. Conch., 1 vol. vii., p. 15̋3 (Nov., 1871).

This species might be mistaken at first sight for $Y$. lanceolata, but when carefully examined it is seen to be quite distinct. It is a larger species than lanceolata, and the diagonal sculpture does not extend beyond the midclle line of the shell, while in the last named sprecies it reaches to the anterior margin.

Y. seminuda was described from St. Paul's Harbour, Radialk, 17 fims. My specimens were dredged outside Victoria IIarbour, and the speeies has not so far been recognized elsewhere in the province.

38. Toldia limatula, Say, sp.

Nucula limutula, Say, American Conchology, pt. ii., pl. xii. (April, 1s:31).

I dredged this species in Departure Bay in 1885, and near Victoria in 1891. It is like the two last named species in colour, but lacks the diagonal grooves they both possess.

This shell was identified for me by Dr. Dall.

39. Youdia, species.

Three time specimens of: a Yoldia that I have not yet identitied were obtained last year in Sooke Harbour by Professor Macoun. The species resembles $Y$. limatula in colour, but differs in its very peculiar shape.

40. Yoldia ang dalea. Valenciennes.

Zool. Voy. Vemus, Mollusca, pl. xxiii., fig. fi (1st6i).

This species has been dredged at Victoria, Departure Bay and C'omox, but appears to be rather rare. Its dark colour and the absencer of the diagonal sculpture distinguish it from the preceding species.

1 The paper in which $Y$. seminuda and some seven or eight others of our British Columbian speciesare described is entitled "Descriptions of 60 new forms of Molluski from the west coast of North America and the North Pacific Ocean, with notes on others already described." It was published in the Americau Journal of Conchology for 1871 , vol. vii., pp. 93 to 160 , plates 13 to 16 .

Sec. IV., 1895. 3. 
Mr. L. A. Snith (in Ann. Mag. Nat. Hist., series 5, vol. vi., 1. 289 [1s80]) (lescribed Yoldia Vancouverensis, n. sp., from a specimen taken near Victoria. Judging by the description, Vancouverensis must be placerd in the synonymy of $Y$. amygdalea.

VHiNERICARIIA, Jamarek.

41. Venericardia Ventricosa, Gould, sp.

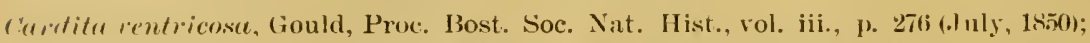

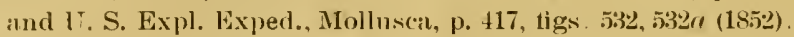

Very common, occurring with Nucula castrensis in all localities yet. cximined. Our shells are certainly the V. ventricosa of Gould, but this species was considered by Carpenter to be a variety only of $V$. borealis, (conral (Amer. Mar. Conch.), and this last is consequently the name usually given in our lists. Lately, however, Dr. Stearns' has figured and compared the two forms, and has pronounced them to be distinet.

Mr. Whiteaves (in Rept. Prog. (ree. Surv. Canada, 1878-79) speaks of both forms as occurring in Dr. Dawson's Queen Charlotte Islands collection. All the local specimens I have seen are ummistakably ventricosa.

CARDITA MERA, Comad.

42. ('arditamera subquadrata, Carpenter', sp.

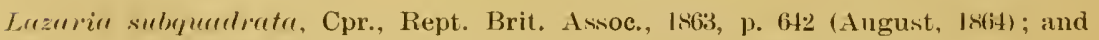
Anu. Mag. Nat. Hist, series 3, rol. xv., 1). 17s (March, 1\&65).

'This shell was first recorled from these waters by Carpenter on the strength of a single valve in Swan's collection; exact locality not stated. Single valves are not uncommon among shells brought by the Indians from the western and northern coasts, and I have myself found valves on the beaches near Victoria. So far, however, the species has not been found here alive.

\section{MIODON, Carpenter.}

43. Miodon prolongatus, Carpenter.

Rept. Brit. Assoc., 18t33, p. 612 (Augnst, I861); and Ans. Mag. Nat. Hist., series 3, vol. xiv., p. 4.24 (December, 1 sisit).

This is not a common shell with us. A few specimens have been found at Victoria, Departure Bay, and at Salt Spring Island, in some instances in sand between tide marks, and in others in deeper water.

Further to the north it appears to be more plentiful, for Mr.

"Scintific Results of Explorations by the Truited States Fish Commission steamer Albatross. XVII. Descriptions of new West American Land, Freshwater and Marine Shells, ete." Proc. U. S. Nat. Museum, rol. xiii.. no. s1:3 (1890). 
Whiteaves records it from "Dolomite Narrows, abundant; mouth of Cumshewa Iarbous, in twenty lathoms, several; Houston-stewart Channel, in fifteen to twenty fathoms, three or four specimens."

ASTAR'T'E, .l. Sowerby.

44. Astarte undata, fiould.

Invertebrata of Massachusetts, p. $80(18+1)$; ed. ii., p. 121.

This species was recorded by $\mathrm{Mr}$. Whiteaves from Metlakatla in 1878 as Astarte semisulcata, Teach ?

In 1886, atter an examination of the speeimens collected by Dr. Dawson to the north of Vancouver Island, he withdrew this name and substituted, and we think rightly, A. undata, Gould, which name we have adopted for our largest Astrarte. This is not by any means so abundant a shell here as is the next sprecies, but it is fairly common at Victoria and in other localities in which dredging hals been done on the eastern and northeru coasts of Villcouver Island.

\section{Istakte Esqumalit, Baird, sp.}

C'rassretella Estquimalti, Baird, Proc. Zool. Soc., London, 1863, p. 70, pl. ii., tig. 15. - Rictocyma mirabitis, Dall, Amer. Jour. Conch., vol. vii., p. 151, pl. xiv., fig. 6 (Nov., 1871).

This is our commonest Astarte, and may be easily distinguished by its smaller size and wavy sculpture from the last named species. It is rather rare at Victoria but is abundant at Nanaimo and Comox, and was found by Dr. Dawson at several points at the north of Vancouver Island, and also at the mouth of Cumshewa Harbour, Queen Charlotte Islands.

\section{Astarte compacta, Carpenter.}

Rept. Brit. Assoc.. 1863, p. 64t2 (Angust, 1s64); and Proc. Acad. Nat. Sci. Phila., 1865, p. 57.

A single living specimen was collected by Dr. Kennerley in Puget chound. Dr. Carpenter described it as "Astarte (? var.) compacta," and suggested that it might prove to be identical with A.compressa, Montagu, a European species.

I do not think that any further specineus of this species? have been found.

FisLIA, Turton.

47. Kieldia Laperolsin, Deshayes, s].

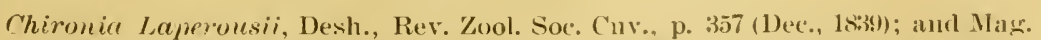
de Zool. (Guerin's), pl. xii. (1811); vitr. Clironii, Cpr., Rept. Brit. Assoc.. 1863, p. 643 (Aug., 1864); and Jour. de Conch., vol, xii., p. 136 (April, 18(i.3).

This is a very common species usually occurring in the interior ot dead bivalve shells. It has been found in all localities in British 
Colunbia in which search has been mate. At Vesuvius Bay, l obtained very tine specimens from the burrows of Penitella penita. In many eases the dead Penitella inclosed Saxicava rugosa, also dead, and containing in its turn numerous specimens of Kellia.

The variety Chironii is characterized by Carpenter as "thinner, less transverse, margins rounded," but the shells of this species are so very variable in shape that it seems hardly necessary to apply a separate name to a particular form.

Fine specimens of $K$. Laperousii frequently exceed $25 \mathrm{~mm}$. in length.

48. Kellia suburbicularis, Montagu, sp.

Hye suborbicularis, Mont., Test. Brit., p. 5ti4, and suppl. p. 39, pl. xxvi., tig. 6 (1803 and 1808).

This does not appear to be so common a shell as the last named, but I think that in many cases it may have been passed over as the young of Laperousii.

I have found the two species together at Victoria and Salt Spring Island, and Dr. Dawson dredged it in several localities near the Queen Charlotte Tslands.

PY'THINA, Hinds.

49. Pythina rugifera, Carpenter.

Rept. Brit. Assoc., 1863. p. 643 (August, 1864) ; and Proc. Acad. Nat. Sci. Phila., 1865, p. 57 .

This species was described from two living specimens obtained by Dr. Kennerley in Puget Sound. No other specimens have been found so far as I am aware.

\section{LEPTON, Turton.}

50). JePton RUDe, Whiteaves.

Rept. Prog. Geol. Surv. Canada, 1878-79, p. 198в, fig. ㄴ.

This curious shell is not uncommon on muddy shores, where it is to be found attached to the ventral segments of a crustacean, Gebia Pugettensis.

The prawn in question is a common species, but in most localities only a small percentage will be found with the attached Cepton.

LASAA, Leach.

51. LasiaA rubra, Montagu, sp.

Curdium rubrum, Mont., Test. Brit., Suppl. p. \&3, pl. xxvii., fig. 4 (1808).

Common near Victoria, generally at the roots of searveed in tide pools. Dr. Kennerley obtained a single specimen of this species in Puget 
Sound, but no recent collectors, with the exception of' myself, secm to have observed it.

As Carpenter remarks. our shells "exactly aceord with british specimens."

$$
\text { TELTAMYA, Brown. }
$$

52. Tellimia tumina, Carpenter.

Rept. Brit. Assne., 1863, p. 643 (August, 1864); and 1'Poe, Acatl. Natt. Sci. Phila., 1865, p. .5.

Common in sand between tide marks all round the coast of $V$ an couver Island and northward to Queen Charlotte Islands.

'The specimen recorded by Whiteaves from Virago Sound as Turtonia minuta, O. Fab., belongs to the present species. I believe that a species of Turtonia is found in the Alaska province. but our shell does not belong to that genus.

CRYPTODON, Turton.

53. Cryptudon skricatus, Cirpenter.

Rept. Brit. Assoc., 1sti3, p. 643 (August, 1s(64): and Proc. Acad. Nat. Sci. Philit., $18(\mathrm{i} \overline{5}, \mathrm{p}, \overline{\mathrm{s}} \overline{\mathrm{c}}$.

Extremely common in sand below low watur mark wherever we have dredged-Esquimalt, Victoria, Sooke, Departure Bay, Comox, west coast of Vancouver Island, and the Queen Charlotte Islands.

54. Cryptodon flexiosus, Montagi, sp.

Tellina flexuosr, Mont., Test. Brit, suppl. p. T2 (1s0s).

A very rare species in this province, thongh rommon in the British seas.

It was first found on the west American coast by Dr. J. G. Cooper who dredged it in 120 fathoms near the Catalina Islands.

Dr. Dawson dredged three perfect specimens in 111 fiathoms at Dixon entrance, Queen Charlotte Islands, and obtained it also in shallow water at False Bay, Straits of Georgia (four specimens), and Quatsino Sound (two specimens). I have myself dredged dead valves in Departure Bay. fathoms.

Jeftreys gives its range in the British seas as three to eighty-seven LUCINA, Bruguière.

\section{Lucina tenursculpta, Carpenter.}

Rept. Brit. Assoc., 1863, p. 642 (August, 1s(it) : and P'rne. Acart. Nut. Sici. Phila., 1865, p. 5.

A very common species, having the same station as Cryptodon sericatus, and occurring in the same localities. It varies a good deal in 
shape, being at times rery tumid and at other times much Hattened. Fine specimens from Sooke measure $9 \frac{1}{2} \times 11 \times 4 \mathrm{~mm}$; others, from Departure Bay, of a quite different shape, $9 \times 9 \times 6 \frac{1}{2} \mathrm{~mm}$.

\section{Jucina acutilineata, Comiad.}

Small living speeimens and larger dead ones have been dredged in several localities from Victoria to Queen Charlotte Islands. Dr. Newcombe found the deal valyes abundant on the shore at low water at Clayoquot Sound

In Whiteaves's papers this species appears as Lucina filosa, Simpson, but Stearns has recently shown that the east coast species is clifferent, and that our shell should be styled Lucina acutilineata, Conrad. Dr. Carpenter supposed this last to be a form of the European L. borealis, Linne, and Jetfreys could see no good reason for separating borealis and filosa.

The three forms are nearly allied and, I should say, are at best geographical varieties of one species. If they are to be united then borealis is of "ourse the oldest name.

DIPLOI)ON'A, Brown.

57. DiPlodonta ORBELla, (rould, sp.

L."rina mbellu. Gould, Proc. Bost. Soc. Nat. Hist., vol. iv., p. 90 (November, 1851 ).

Not common. I have only found dead shells which I dredged in Departure Bay, but Dr. Dawson obtained living specimens at the Queen Charlotte Islands by dredging, and at low water at Malaspina Inlet, and again between Nahwitti Bar and Quatsino Sound, Vancouver Island.

Dr. Newcombe has, reported it as being found in mud at Comox and sialt spring Island. In California it is not uncommon and is found, according to Mr. Orcutt," "in holes in rocks or in dead bivalves."

\section{CARHIUM. Jinne.}

\section{Carbium Nutwalli, Conjad.}

Jour. Acad. Nat. Sei. Phila., vol. vii., pt. 2, p. 22:9, pl. xvii., tig. 3 (16:37).

This species is now generally considered to be distinct from the Pectunculus corbis of Martyn with which Carpenter united it. It is a

3 "Notes on the Mlollusks of the vieinity of San Diego, Cal., and Todos Santos Bay, Lower California," Proe. U. S. Nat. Mus., vol. viii., 1885. This paper and the following: "Ammotated list of shells of San Pedro Bay and vicinity," by Mrs. Bur. ton Williamson, Proc. U.S. Nat. Mus., vol. xv., 1892, as well as the earlier "Geographical Catalogue of Mollusca " (1867), of Dr. .). G. Cooper, and the Monterey list of the same antlor (Amer. Jour. Conch., vol. vi., I870), should be consulted for information as to the southern range of our species. 
fine species and occurs commonly in sand between tiden on all our coasts. It is largely consumed ly Indians and others in the junper season.

\section{Cardun Californitinse, Deshayes.}

Rev. \%ool. Soc. Cuv., p. 360 (Dec., 18:3!) ; and Mag. de \%ool. (Guerin's), pl. slvii. (lsth): var. = C. bluntum, Gould, Proc. Bost. Soc. Nat. Hist., vol. iii., p. 27ti f.huly, $1850)$; and I. S. Expl. Exped., Molluse p. 118, tị. .334, 537a (1852).

This cockle is never found living above low water mark. but has been dredged, though not very abundantly, wherever dredging has been carried on.

At Victoria, where we have had the opportunity to examine a number of specimens; there appear to he two varieties differing in shape and number of rihs. Crould in his description of Cardium blandum, which clearly refers to our shell, speaks of this variation in form. 'The: ribs are often nearly 50 in number, and the interion of the shell is frequently more or less tinted with rose colour.

There is a third species of Cardium (the name of which I halce not been able to aseertain) abundant in the Leda clay at Victoria.

\section{SERRIPES, Beck.}

\section{Serripes (iroenlandeus, Anct.}

Cordium Groentumelicum, ste., Chemnitz, Conch. Cal., vol. vi., p. 2202, pl. xix.. fig. 198. = stentulum, Montagn, lsos (according to Carpenter).

Chemnitz was not binomial in volume vi., and his name is not therefore entitled in strictness to priority. It would serve no good purpose. however to change a name that has come into universal use.

I have dredged deal specimens of this shell at Victorial and Departure Bay, and I)r. Newcombe has obtained it in these places and alive in Deep Bay, near Comox. He also reports it as fossil in the boulder clay in various localities.

\section{Sereripes laperousit, Deshilyes, sp.}

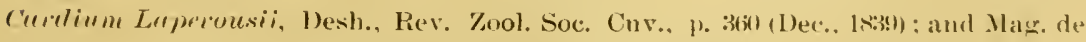
Zool. (Gnerin's). pl. xlviii. (1si1).

According to Mr. Whiteaves a single living specimen of this species was dredged hy Mr. Richardson, near Victoria, in 1875. hut no wher specimens have heen obtained here so fiar as I know. 
62. SERripes centiflusum, Calpenter, sp.

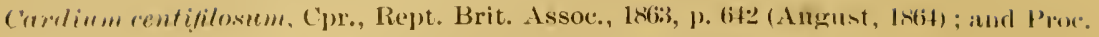
Cal, Acad. Nat. Sci., vol. iii. (1Kitit).

- C. Irlamsi, Tryon, 1871.

- C. modestum, Ad. and Rre., 18ño, mot Philippi lets.

C. Richarlsomi, Whiteaves, 1878 .

'Tryon, in his catalogue of Cardiida', 1871, ignores Carpenter's name and re-names the species Adamsi, on the ground that modestum is preoccupied by Philippi.

Mr. Whiteares, in the "Ottawa Naturalist" for l)ecember, 1893, p. 13 t, acknowledges his C. Richardsoni to be a synomyn of C. modestum, Ad. and Rive, but says that he deseribed it "as a new species almost entirely on the anthority of Dr. Carpenter," who would thus seem to bave failed to recognize his own $C$. centifilosum. There is little doubt, howerer, that all the above mentioned names refer to one and the same species.

S. centifilosum is not a common shell with us. Mr. Richandbon dredged a single living speeimen (the type of $C$. Richardsoni) in $\mathbf{3 0 - 5 0}$ fathoms, between Race Island lighthouse and Victoria Harlour. I have dredged a few living and sereral dead shells in the same locality and in Departure Bay. Other recent collectors do not secm to have met with it.

\section{TENTS. Thinne.}

63. Venus Kennerdeyi, Reeve.

Conch. leon., Mon, of Venus, no. 41, 1863 .

This tine species is not very common. Richardson dredged it alive at Victoria; Dawson took it in some numbers at the Queen Charlotte Islands and subsequently in Dunean and Freshwater Bays. I have myself dredged it alive in Departure Bay. and Dr. Newcombe has found it both liring and dead at Vietoria. It is a dull, heavy shell with strong concentric ribs and distinctly crennlated edges to the valves

PSEPHIS, Carpenter.

64. Psephis tantidia, Gould, sp).

Vemus /untillus, fronld, Bost. Jour. Nat. Hist., vol, vi., no. 3, p. 416, pl. xi,, fig. 10 (October, 185;3).

Plentiful in sand between tide marks near Victoria, and also common, ateorling to Dr: Neweombe, at Comox and Clayoquot. Professor Macoun also collected it at Sooke. Dr. Dawson did not find it at the Queen Charlotte Islands or elsewhere, but as he did very little shore collecting he might easily pass over so small a whell. 
Gould's type was from Santa Barbaral, and Dr. Cooper lledgerl the species in that neighbourhood in 12 to 20 fathoms. As staterlabore our specimens have all been taken between tides.

\section{P'SEritIs JoRDi, Baird, sp.}

Chime Lomeli, Baird, Proc. Zool. Soc. L.0ndon, IN(3), 1. 69. pl. ii., tiщ. 10.

This shell is quite as common as the last named, but as it inhalits leep water it (an only be obtained by dredging. It has been found in nearly all the localities in which collections have been made. Dr. Newcombe speaks of tinding it at extreme low water; Dr. Dawson, on the other hand, dredged it at a depth of 111 fathoms. Its usual station seems to be in clean sand in 10 to 30 fathoms in company with Mesalia reticulata, Cryptodon sericatus, ete. The absence of the purple stain readily distinguishes this species from $P$. tantilla. which is morenver a much smaller shell.

CLWMENTIA, Ciray.

66. Clementia subidaphana, Cirpenter.

Rept. Brit. Assoce, 18(33) p. 640 (August, 1864): and Proc. Acar. Nat. S'ci. Philit., 1865, p. 56

Generally distributed, but not common. It has been dredged by Dr. Dawson in Quatsino Sound and at the Queen Charlotte Islands; by Dr. Newcombe at Comox, Clayoquot, etc.; by myself at Departure Bay and Victoria. The young shells are generally coated with sand, like Iyonsia and some other species.

TAPEs, Muhltuldt.

67. Tapes struinea, Conrad, sp.

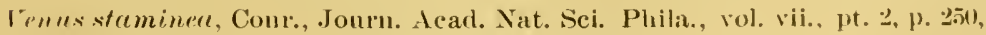
pl. xix., fig. 14 (18ïi).

$=$ Venerupis Petitii, Deshayes, 18:39.

= Veuus rigida, Gould (pars), 1850 .

vas. = diverset, Sby.: ruderata, Deslı.: tumida, Slyy:: orbellu, Cpr., etc.

Very common between tides, generally amonir stones on muddy shotes. This species varies mueh in shape and sculpture. Sometimes it is found in the burrows of Penitella penita and is distorted after the manner of Petricola. The colonr is also variable, the common variety being white, but some specimens are almost as brightly coloured as the Californian Tapes grata. An extreme rariety is dark choeolate colour.

Tapes staminea is a common article of fool. 
68. Tapes tenerrima, liould and Carpenter.

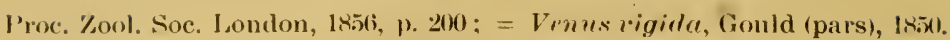

'This tine species is not nearly so common as the last named. I have only found it in one locality, namely, Cadboro' Bay, near Victoria, where it nccurs in sand between tide malks. Dr. Newcombe has found it in a similar situation at Clayoquot soumd.

In a systematie arrangement our nine species of firesh-water Corbiculide must be placed here.

They are:

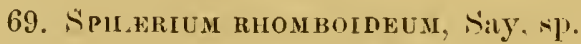

70. " TUMUU, Baird.

71. " SPOKANI, Baird.

72. " RaYnondi, J. (i. Cooper.

73. Pisidiun variablle, Prime.

74. “ ABDitum, Haldeman.

75. " " ultramontanum, Prime.

76. " sp.

77. " sp.

All of the above have been taken by myself on Vancouver Island, except $S$. tumidum and S. Spokani, which were described by Baird from localities on the mainland of British Columbia.

\section{SAXIJOMUS, Conrad.}

\section{Saxidomes SQualidus, Deshayes.}

Brit. Mus. Cat. of Veneride, p. 18s, no. 5 (1853).

Very common everywhere between tides, and largely used by Indians and others : as an article of food.

PETRTROLA, Lamarck.

79. Pétricola carditoides, Conrad, sp.

Sierrimere rardituides, Conrad, Jour. Acad. Nat. Sci. Phila., vol. vii., pt 2. p. 205,

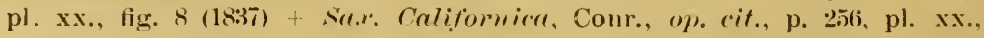
lig. 9.

This is the name by which this shell has hong been known, though there appear to be sereral older ones, e.g.. nivea, Chem., rugosa, Sby., and tenuis, sby.

C'apenter records it from Puget Sound (Kennerley) and V anconver Island (Swan). Richardson is said to have found four living specimens at Virotoriat in 1875, and Dr. Newcombe obtatined young specimens at 
Clayoquot last autumm. I do not know of any other recond of its coreurrence in this province, and I have never taken it myself:

PSA MMOBIA, Lammark.

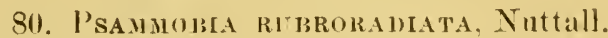

This species seems to be ralle, or at any rate difficult to tind. It was represented in the collections of liennerley and Swan hy dead shells, and single valves have been found in many localities on all our coasts from Victoria to the Queen Charlotte Islands. I have not seen living specimens, but I heliere that 1)r. Newcombe found a tew at Comox and at Clayoguot.

MOERA, II. and A. Adams.

81. Moera salionea, Carperiter.

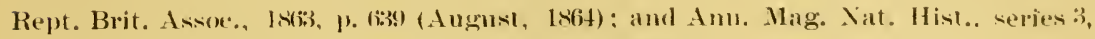
vol. xiv., p. $42: 3$ (18it).

Found hy Dr. Dawson in several northern localities,-- (puatsino, Sound, Queen Charlotte Sound and Qmeen Charlotte Islands. Also by Dr. Newcombe at Clayoquot Sound. A few specimens were kindly given to me some years ago by Capt. Clarke, who had dredged them near Comox. I have not seen any specimens from Victoria or Ninaimo.

ANGULUS, Muhlteldt.

82. Angulus modestus, (Mapenter.

Rept. Brit. Assoc., 18(i), p. (i3)! (Angust, 1864); and Proc. Acad. Nilt. Sici. Philit., Isio, 1. oli; var. = A. obtuesss, Carpenter.

This little shell is eommon in sand between tides, and is sometimes found in deeper water. Dr. Dawson took it at the north of Vancruver Island, but not near the Queen ('harlotte Islands, Dr. Neweombe found it at Clayoquot, and it is abundant at Victoria, Departure Bay and ('omox.

\section{Angliss variegatis, Carpenter.}

Rept. Brit. Ansoc., 1s(i3), p. (i39) (Angust, 18(it): and Anu. Mag. Nat. Ilist., series:3, vol. xiv. p. 424 (1si(i)

This species was one of Swan's auditions to the Vancouver list. and it was stated by him to be "rare." Only al single specimen has been found here since Swall's time, and that has been recorded by Mr. Whiteaves as "a fully grown living specimen." taken by Dr. Dawson at (quatsino sound in thirty to tifty fathoms. (Trans. Riry. Soc. Canada, 1886.) The record of $A$. variegatus in $\mathrm{Mr}$. Whiteases's eallier juller (in 
Rept. Prog. Geo. Surv. Can., 1578-79) is said by him to be a misprint, and to refer to Moera salmonea. A. variegatus is not rate on the Califormian coasts.

$$
\text { 84. Angulus liorlubr, Carpenter. }
$$

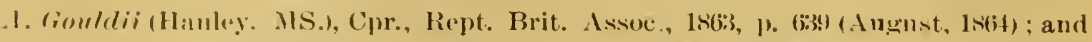
Jour. de Conch., vol. xii., p. 132 (April, 18(in).

This shell is recorded by 1)r. Neweombe in his paper in the "Bulletin of the Natural llistory Society of British Columbia" as having been found by himself at Comox. He adds to his mote: "Mr. Dall states that these may be the young of " $T$. inflatula."

$$
\text { PERONAA, Poli. }
$$

\section{P'ERonia Bodegensis, Hinds, sp.}

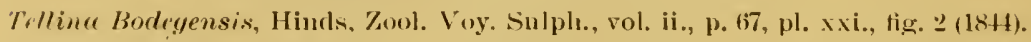

This species appears to be confined, in this province, to the western and northern coasts of Vancouver Island.

Dr. Dawson took six living speeimens between Nahwitti Bar and Quatsino Sound, and Dr. Neweombe found specimens, also living, at low water at Clayoquot Sound.

I have seen a few specimens from other west coast localities, but have never taken this species on the eastern side of the island.

MACOMA, Teach.

86. Macoma secta, Conrad, sp.

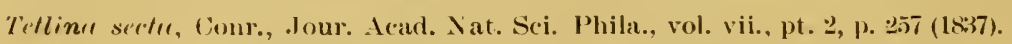
= ligamentime, Deshayes, 1843. (A most appropriate name.)

Of our many native Macomas this is the first and tinest. It is found in sand near low water in nearly all the localities examined; specimens from the west coast appearing to be rather larger and heavier than those from the neighbourhond of Victoria.

Dr. Newcombe, in his paper so often quoted, credits Dr. Dawson whth having taken this species at the Queen Charlotte Islands, but I (aunot find the record in Mr. Whiteaves's report of Dr. Dawson's collections. As before mentioned, Dr. Dawson does not appear to have made any special search for shore shells, and may therefore easily have overlooked this species, which, however, douhtless oevurs in the localities he risited.

Carpenter speaks of a variety edulis, Nuttall, as being the northern form of secta, and as oceurring in Puget Sound.

87. Micoma nasuta, Conrad, sp.

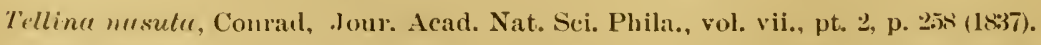

This and the next named speeies are very abundant between tides on all our coasts, and in their season are often exposed for sale in the Victoria markets. 


\section{Macoma inguinata, Deshayes.}

Proc. \%oul. Sice. Iondon, 1454, 1. 35\%.

Tery common; set note under last species.

89. Macoma mentura, Broderij) and howerby, sp.

Tellima erlentule, Br, and sby., Zool. Jomr., vol. iv., pt. 15, p. 3633 $11829 \%$.

This is the name 1 apply to a Macoma that I have not infrequently dredged at Nanaimo (but always dead), and which I have also fonnd living in sand between tides al Curdova Bay.

It bears some resemblance to a very large valriety of $M$, inconspicua, and possibly the large specimens from False Head, Vancouver Island, recorded by Mr. Whiteaves as $M$. inconspicua, may prove to be the present species.

Dall's tigure of his Macoma Middendorffi (= edentula. Middendortt, not Brod. and Sby.) Proc. U.s. Nat. Musenm, 1886, pl. iv., tig. 11. ${ }^{1}$ is wonderfully like some ipecimens of our shell.

!0. Macoma rata, (imelin, sp.

Tellim luta, Ginel., Syst. Nat., ed. xiii., vol. i., pt. 6, p. 3237. (I7xs).

- T. culcarca, Chemnitz. 178"2. (Not binomial).

- 'T' subulosa, Spengler. 1798.

T. proxima, Brown. Etc.. ete.

This form is quite different to the one last named. I have found it (dead) wherever I have dredged, and it is a not uncommon fossil in the Leda clay. Dr. Dawson obtained living specimens by dredging at Dixon Entrance in 111 fathoms: and in Quatsino Sound in shallower water.

Mr. Whiteaves adopts the specitic name sabulosa in his first report and calcarea in his second. As hefore mentioned (under Serripes Gronlandicus), Chemnitz in volume vi. of the Conchylien Cabinet is not binomial, and therefore his name should not be used. and Spengler's name is ante-dated by the appropriate one of Gmelin.

In this paper, which is entitled "Supplementary notes on some specien of Mollusks of the Behring Sea and vicinity," Dr. Dall his interesting notes on several of our specius besides the Macomu erlentulu, namely : Mangilia levidensis, Brtusculphuratu, Almete Couthonyi, Trophon muricimrmis (= Dullii), $T$. orpheus, $T$. tenuisculptus and Alrania castunca. Also excellent figmes of M. Midendorfti (sfe alove), B. sculpturata, T. Dolli and A. ctostancel. Dr. Dall has previonsly called attention to $M$. colentula in a paper in the same Proceedings, vol. vii.. 1sist. 1). 347 . 


\section{Macoma expansa, Carpenter.}

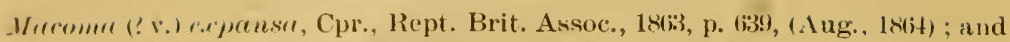
Proc. Acad. Nat. Sci. Phila.. ls'i5, p. of.

This is the name applied by Dr. Carpenter to some shells obtained by Dr. Kennerley in Puget Sound. Dr. Carpenter himself noted the (ase resemblance to lata $=$ calcarea, and I suspect that $M$. expansa will prove to he only a variety of that species.

92. ILacoma inconspicua, Broderip and Sowerby, sp.

Trllin, incomsprirue, Br. and Slby., Zool. Jour., vol. iv., pt. 15, p. 3633 (1829); and Zool. Voy. Bloxiom, p. 153, pl. xli., fig. (i (18:3!).

Verg common and rariable. Found everywhere in sand between tides.

Jeffreys and others have united this species with Macoma lata. By. a similar process of lumping together allied forms, the number of species of Macoma may be considerably reduced, but there seems little doubt, to my mind, as to the specific distinctuess of all the forms above enumerated. On this coast, at any rate, they do not seem to intergrade at all.

\section{Macoula Carlotensis, Whiteaves.}

Rept. Prog. Geo. Surv. Canada, 1×78.79) p. 196ib, fíg. 1 (1879).

This species is only known to us from the original description and specimens. The latter were obtained by I)r. Dawson in 1878 in "Virago sound in firom eight to tifteen fathoms, abundant."

\section{Macoma yoldiformis, Carpenter.}

Rept. Brit. Assoce, 1N(i3, 1. 6339 (August, 1864); and Proc. Acad. Nat. Sci. Philat., 1865, p. .ก๊.

Described from speeimens from Puget Sound (Kennerley) and Vancouver Island (Swan). It has since been obtained by Dr. Newcombe and myself by dredging in various localities on both the east and west coasts of the island, and it is probably widely distributed.

The "Macoma, n. ㄱ."." mentioned by [1). Neweombe, in his list, at taken at Clayoquot Sound, seems to me to be identical with this species.

\section{Macoma inflatula. Dall.}

(See note mnder Augulus (iouldii.)

Edalina subdiaphana, Cpr., is in Dr. Newcombe's catalogue, with the note, "One living specimen at low water ('layoquot Sound." The 
specimen, which I have seen. is not an Fdalina. hut may belong to the last named species of Macoma.

CLMINGIA. Sowerby.

96. Cumingia Californica, Cramiad.

Jomrn. Acad. Nat. Sci. Phila., vol. vii., pt. 2, p. 2234 , pl. xvii., fig. 122 (1\$37).

This species is included in our list on the strength of Mr. Whiteaver'; record (in the Ottawa Naturalist for December, 1893) of a single specimen collected by Professor Macoun in 1887 at Barclay Sounil.

SEMELE, Sehnmacher.

97. Semele rubropicta, Dall.

Amel. Jour. Conch., vol. vii., p. 144, pl. xis., tig. 10 (November, 1871).

This is the shell that Californian conchologists, following Carpenter. (alled S. rubrolineata, Conrad, hut Dr. Dall, helieving, as Dr. Carpenter himselt suspected, that it is not the species intended by Conrad, has redescribed it, with an excellent figure, in the American Journal of Conchology, loc. cit

The shell is by no means common, but has been found, deal, at Tietoria and Departure Bay, and, by Dr. Newcombe, at Clayoqunt.

SILIQUA, Muhlfeldt.

98. Siligla patula, Lixon, sp.

Solen patulus, Dixon, Voyage, etc., p. 355, tig. 22 (1789).

This fine species is more common on the west and north than on the east coast of Vancouver Island, though both Dr. Newcombe and myself have dredged young specimens near Victoria.

Dr. Dawson found this shell dead on the beach at Marset and Rosec Point, Queen Charlotte Islands, and Dr. Newcombe procured tine living specimens in the sands, letween tides, at Clayoquot. I have received these shells also from other points on the west Vancouver const.

I have not beard of this species being sold or used for fool in this province, hat the first discoverers of the shells, Captain Dixon's crew, are said to have preferred them to the cockles. C. Nuttalli, that alonuder in the same locality.

$$
\text { SOLEN, Lime. }
$$

99. Solen sicartus, Fould.

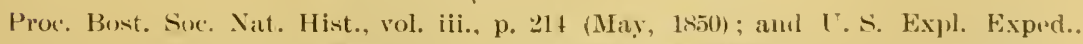
Mollusca, p, 357, tig. .501-501h (1852).

Generally distributed, but not easy to obtain, ats it lives huried rather deeply un sand below low water-mark, and is consequently seldom 
dredged except when rery young or when dead. The dead shells in greater or less number have been found at Victoria, Departure Bay. Comox and Clayoquot.

SP'ISULA, Gray.

100. Sinsula falcata, Gould, sp.

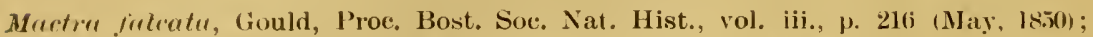
and U. S. Expl. Exped., Mollusea, p. 393, fig. 506-506b (18522).

This species has been found dead by Dr. Dilwson at the Quexen Charlotte Islands, and by Dr. Newcombe at Comox and Victoria.

In Carpenter's "Supplementary Report" it is given as from Puget Sound (Kennerley) and Vancouver Island (Swan). I have not myself as yet succeeded in finding specimens.

\section{Spisula planulata, Conrad, spl.}

Martma planulrta, Conr., Journ. Acat. Nat. Sei. Phila., vol. vii., pt. ㄹ, p. 240 (1\$37).

Of this species I have dredged numerous young specimens in Departure Bay. Dr. Newcombe has found it at Clayoquot, and Mr. Harvey at Comox.

Dr. Dall, finding the nomenclature of the Pacitic coast Mactride in a very unsatisfactory condition, has been lately working up the subject. A first paper by him, entitled, "On the Species of Mactra from California," has appeared in the "Nautilus" for April of the present year and should be consulted for notes on our species.'

$$
\text { I) ARINA, Gray. }
$$

\section{Darina Declivis, Carpenter.}

Rept. Brit. Assoc., 18633, 1. (637 (August, 1864); and Proc. Zool. Soc. London, 1865, p. 203.

A single shell, measuring $1.77 \times 85 \times 34$ inches, was found at

1 Since the above was written Dr. Dill has published several other papers on North American Mactridu. In one of these entitled "Synopsis of the Mactrida" of Northwest America, South to Panama," published in the "Nautilus" for Angust, 1894, Dr. Dall names the northern species as follows:-

Mactra (Martrotoma) Califormicr, Conrad. Fuea Strait to Central Arserica.

Spisulu (Hemimactra), molynyma, Stimpson, var. Alaskuna, Dall. Iey Cape to Neeah Bay.

Spisula (Hemimactra cutilliformis, Conrad. Neeah Bay to Sall Diego.

Sprisula (Hemimartra) plamulata, Conrarl. Monterey to San Diego.

Spisula (Symmorphomactra) falcretu, Gould. Comox to San Pedro, Cal.

I have not yet found specimens of the three first named species among our Villcouver shells, nor am I very confident as to the correctness of the identifieation of the specimens. I have reeorded above as $S$. planulata. 
Vancouver Island by Dr. Forties, and mate the type of this species by 1)r. Carpenter.

The latter remarks, in his note on the species, that it "may have been passed over as the young of Machora (Siliqua) patula, to which it hear's a strong extarnal resemblance."

No further specimens seem to have bcen fouml.

TRESUS, Gray.

103. Tresus Nuttalli, Conrad.

Lutraria Vuttrlli, Comr., Iomm. Acad. Nat. Sci. Phila., vol. vii., pt. 22, p. 2:35, pl. xviii., tig. 1 (1837).

This is the clam of the North Pacitic coast. It is very common on all our sandy beaches and is an important article of food anong the Indians, who, in summer, collect and dry the animals for winter consumption. A little crab, Pinnotheres faba, Dana, finds its lodging within the valves of this shell.

THRACIA, Leach.

104. T'hracia curta, Conrad.

Journ. Acad. Nat. Sci. Philit, vol. vii., pt. 2, p. $248, p l . x i x$, tig. $\diamond(1 \times 37)$.

This shell has not yet been found in any numbers, though it serems to be widely distributed.

Dr. Dawson took one specimen in Virago sound, Queen Charlotte Islands, and a large single valve in Quatsino Sound. Dr. Newcombe has dredged it alive in Clayoquot sound and at Comox, and I have dredged it alive at Departure Bay and have taken a few dead specimens near Victoria. A valve from the last named locality measured $57 \mathrm{x}$ $46 \mathrm{~mm}$., being a little larger than the one from Quatsino sound of which Mr. Whiteaves gives the measurements (Trans. R. S. Can. 1886, sec. iv., p. 123).

\section{Thracia beringi, Dall, MS.}

This species has long been known to Dr. Dall, and though not yet described, I believe, has been distributed under the manuscrijt name T. Beringi.

In 1888, 1 dredged a large single valve $(58 \times 4: 3 \mathrm{~mm}$.) and al small number of young living specimens of this species in Departure Bay. These were all submitted to Dr. Dall who kindly determined them for me as above. 
LYONSIA, 'T'แITOH.

106. Lionsia californica, Conmad.

Jomm. Acadl. Nat. Sci. Phila., vol. vii., pt. 2, p. 2245, pl. xix., fig. $20(1 \times 3 i)$.

= nitirla brecteatre, Gonld: (according to Carpenter.)

Common everywhere in sand between tides. I have taken at Victoria an unusnally large form which at first I was tempted to treat as a distinct species, but Dr. Dall who kindly examined it considers it to be merely a northern variety of Californica.

\section{ENTODESML, Philippi.}

107. Entodesma saxicola, Baird. sp.

Lyonsire suricole, Baird, Proc. Zool. Soc. I,ondon, 18(ii, p. 70, pl. ii., fig. 14.

Generally distributed; living in crevices of the rocks between tide marks. but not found anywhere in large numbers.

\section{MYTILIMERIA, Comrad.}

\section{S. Mytilimeria Nitralli, Conrad.}

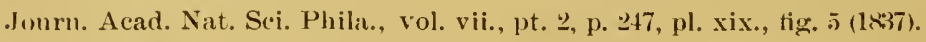

Never yet found by us in any numbers but apparently generally distributed. Living specimens have heen taken at the Queen Charlotte Islands and Victoria; dead shells at Comox ("very large" Harvey), Clayoquot Sound and elsewhere.

CUSPIDARIA, Nardo.

109. Cuspidaria pectinata, Carpenter. sp.

Nen ire pretimutu, Cpr., Rept. Brit. Assoc., 1s(i3, p. 637 (Augt., 18(i4) ; and Proc. Acad. Nat. Sci. Phila., 18(i.), p. 54.

The generic name Neara, (ipray (1834), is said to be preoceupied in Dijitera.

C. pectinata is recorded by Carpenter from Puget Sound (1 specimen, Dr. Kenmerley). It seems to be quite a common shell with us. having been taken in from 10 to 20 fathoms, in all the localities in which we have dredged. The shells are usually somewhat less than half an inch in length, but $\mathrm{Mr}$. Whiteaves records an extraordinarily large example from Quatsino Sound measuring $21 \times 13 \mathrm{~mm}$. 
CLIDIOPHORA, Car'mnter.

110. ('Lidophora punctata. ('omaid, sp.

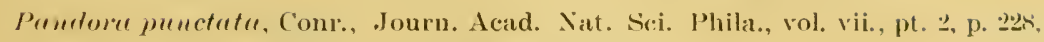
pl, xvii., fig. 1 (1\$:37).

Not uncommon in California but only known from this province, at the time of Carpenter's report, by a single valve in Swan's collections. In 1892, however, Mr. E. S. Wilkinsun brought dead valves from the west coast of Vancouver. Island, and last year Dr. Newcombe found a number of dead shells and also dredged a few living specimens in clean sand in shallow water at Clayoquot Sound.

KENNERLIA. Carpenter.

111. KennerLia grandis, Dill.

Pantora (Kenmerlin) yramdis, Dall., Proc. Cal. Acad. Sci., rol. vii. (1ล7T).

Described from Unalashka. First found in British Columbian waters by Richardson in 1875. Afterwards in 1885 by Dr. Dawson, in Duncan Bay and lorward Bay. The only other locality in which it has been taken so far is near Victoria where it is not rery rare in 10 to 30 fathoins, sand.

\section{Kenneria frlosa, Carpenter.}

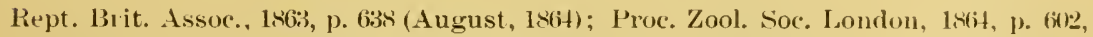
and Proc. Acad. Nat. Sci. Pliila., 186ã, p. 5̄.

Much commoner than the last and more generally distributed. It has been dredged in 8 to 50 fathoms (sand) in Virago Sound. (Queen Charlotte Islands, Quatsino Sound and Straits of Georgia, by Dr. Dawsou; in Clayoquot Sound by Dr. Newcombe and in Departure Bay (where it is common) and at Victoria by myself.

SPH.TiNIA, Turton.

113. SPHænla ovoldfa. ('arpenter.

Rept. Brit. Asso(., li63, p. 6337 (Augnst, 1864) ; and Proc. Acarl. Nat. Sici. I’hila., 1865, p. 54.

Thecribed from one living specimen taken by Dr. Femmerley in Puget Sound. I have no linowledge of any further specimens having been taken. 


\section{CIIYPTOMYA. Conrad.}

114. Cryptomya (Aalfornica, Comiad, s])

Sphernier Calitmmierr. Conr., Journ. Acad. Nat. Sci. Phila., vol. vii., pt, 2. p. 2234, pl. xvii., tig. 11 (18:37).

A very common whell in this province. It is found on mudly shores between tide marks.

MYA, Linne.

115. Mra troncata, Limne.

Syst. Nat., ed. xii., vol. i., pt. ㄹ, p. 111\%, no. 26 (1767).

This common tinropean shell is generally distributed throughout the province. It prefers a muddy rather than a sandy shore and is not confined to the beach but is often found in deep water. It is a common fossil in the Boulder Clay.

Mya procisa, Gould described from Puget Sound, is said by Callpenter to be a synonym of this species, but other authors refer it to M. arenaria. Gould's description would answer well for a young specimen of the latter, the original figure I have not been able to see.

\section{Mya arenaria, Limme.}

Syst. Nat., ed. xii., vol. i., pt. 2, p. 1112, no. 27 (1767).

This species is a puzzle to me. If it is the $M$. precisa of Gould, or if as Dr. Newcombe asserts it is a frequent fossil in the Boulder Clay it must of course be considered a native of the province. On the other hand, although I had searched the beaches near Victoria for several years previously, I never found a specimen alive or dead until 1888, in which year I dredged a few specimens of the firy in Departure Bay.

On $m y$ return to Victoria in 1890 , after an absence of two years, I found $M$. arenaria in thousands in the very spots that $I$ had searched over and over again in previous years and in which it conld hardly have existed withont my tinding it.

So that whether $M$. arenaria is a native or not, I am fully persuaded that the thousands of specimens now living in every sandy shore from Victoria to the northern extremity of Vancouver Island are descendants of speeimens introduced within the last few years. There seems to be pretty good evidence that $\boldsymbol{M}$. arenaria was introduced near San Franeiseo with oysters from Eastern America (for as is well known M. arenaria is a rery common Atlantic shell), and has multiplied proligiously, and possibly it has spread up the coast until our province was reached some four ar tive yeuns ago. 
SAXICAVA, Bellevue.

117. Saxicava Rugosa, linne, sp.

Mytilus rugonus, Linme, syst. Nat., ed, xii. vol. i., pt. 2., p. 1156, no. 249 (1767).

Myr arefica, Limne, op cit., N. 1113, no. 32 (17677).

solen minutus, Limne, op. cit., p. 1115, no. 4ำ (1767)

Mytilus pholarlis, Linue, Mant. Plant., p. J̆(1771).

Arctica is the earliest specitie name for this shell, but it was applied by Linne to a variety while the name rugosus was given to the typieal rock-boring form. Pholadis, a still later name, was given to another variety, which appears to be our commonest form, and this name is the one generally used in recent west coast lists.

This shell is very widely distributed and common in this province, as throughout the world, occurring sometimes nestling at roots of seaweed, sometimes attached ly a byssus to the rocks in tide pools and sometimes in the humows of Penitella.

My two finest sprecimens have been taken in the last named station and measure respectively $55 \times 25 \times 25$ and $48 \times 25 \times 25 \mathrm{~mm}$. A narrow specimen measures $45 \times 14 \times 16 \mathrm{~mm}$. These all belong to the variety that has the shell gaping widely in front and to which. Teffreys (Brit. Conch., vol. iii., p. 82 ) restricts the name pholadis.

PANOP.EA, Menard.

118. Panop.tia Norvegica, spengler, sp.

Iyn Norregien, Speng., Skrivt: .'at. Selsk., vol. iii., p. 16, pl. ii., tig. 18 (1793).

This is a rare species both in linrope and in Americal. In our province it is only known from small dead shells which hare been dredged near Victoria by Dr. Newcombe and also by myself.

\section{Paxol, tia Gexerosa, fould.}

Proce Bost. Soc. Nat. Hist., vol. iii, p. 2[5, (May 1850) : and I. S. Expl. Exped.. Molluscat, p. 385. tig. 5017-507b (1850).

This large species lives at a considerable depth (more than two feet) in the sand, and consequently is not easily obtained. Moreorer it does not appear to be at all common on our coasts. Wead shells have been dredged at Victoria and Comox by Dr. Newcombe and kately that gentleman and $\mathbf{M r}$. Spreadborongh discorered living specimens at Clayoquot sound. I believe that this species is more albundant in Puget sound. It also aecors on the Californian (o)asts. 
NETTASTOMELLA, C'apenter.

120. NetTastomelda 1)arwinnil, Sowerhy, sp.

Pholas Durwinii. Shy.

One specimen was obtained at Vancourer Island by Mr. Lord. The species was originally lescribed as from Chili. It has since been found at Monterey (Rich) and han I)iego (Conper) teste ('arpenter.

P'ENJ'TELLA. C'onrad.

121. Penitella penita, Comial, sp.

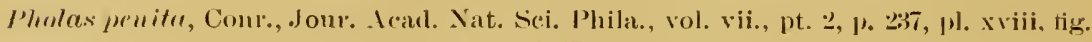
$7(1837)$.

Common all round the coast of Vancouver Island, perforating sott rocks between tides. At Vesurius Bay. Salt śpring Island, I have found very tine specimens measuring more than $3 \frac{1}{2}$ inches in length and nearly 6 inches in circumference at the umbones. This species is said by Dall ' to be found at Bering Island with Saxirava rugosa "living in Iarge masses of Melobesia, which form accumulations almost like colal on the exposed coasts."

122. PENITELLA "VoIdeA, Gould. ne.

Ploolres moirlea, (iould, Proc. Bost. Soc. Nat. Hist., vol. ir., p. st (Nov., 1851).

I am not sure that I know this sprecies. It was described from Monterey, and Carpenter in his "supplementary Report" gives it a southeru range. Fpecimens that I have received from California under this name are indistinguishable from $P$. penita. Mr. Whiteares in his account of Mr. Richardson's collections says that he collected four living specimens of $P$. penita and tour of $P$. ovoidea, near Victoria in 1875 . He further says that penita has "Siphonal tube winkled but not tuberculated" while oroidea has "siphonal tube tuberenlated externally, especially near the middle."

Through the lindness of Mr. Whiteaves one of Richardson's specimens is in my cabinet, but though it manifestly differs from typical penita it does not to my mind accord sufficiently wel] with Crould's description of oroidea.

1 "Report on the Mollusca of the Commander Islands and Bering Sea, collected ly Leonhard Stejneger in 1882-3." Proc. U. S. Nat. Mus., vol. vii. (18't), p. 34s-349.

In the same loeality with $P$. penitu were fonnd: Mytilusetulis. Morliolu montiolu.

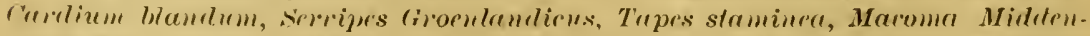

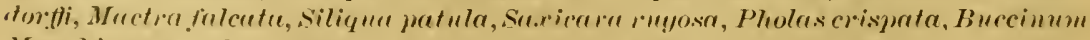

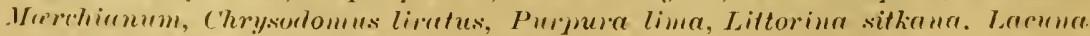

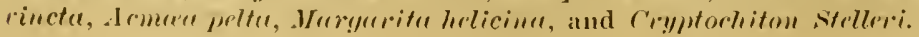


Dr. Newcombe informs me that he has lately found on the beach near Victoria a shell which Dr. Dall has determined for him as Penitella tubifera, Sby. Tryon has also described Penitella curvata, from the Straits of Fucar (Amer. Jour. Conch. vol. i.. 1). 41), pl. ii., tig. 6. 7 ind 8 (1865).

$$
\text { ZIRPII.RA, Le:ach. }
$$

12:3. Zirphata crispat, Limne, sp.

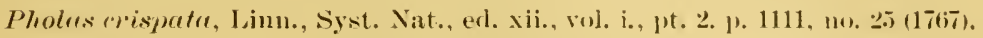

This speeies is not uncommon in Europe and on the calsterll coasts of Americal. In the Pacific it is recorded by Carpenter as from Puget Sound (two specimens Dr. Kennerley) and with a query from Swan's collection.

Dr. Dawson found a large worn right valve on the beach north of ('umshewa Harbour, (queen Charlotte Islands, and I found some fine specimens living in sand between ticles at Cordora bay ten year's ago, but have never had an opportunity of revisiting that locality and have not heen fortmate enough to find specimens anywhere else.

XYLOPIIAGA, 'Turton.

124. Iylophaga norsalis, Turtom, sp.

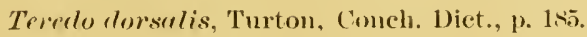

Specimens taken by myself in 1888 were I believe the tirst noted on the Pacific coast of America. 'They were found living in small pieces of drift wood dredged up in Departure Bay. The shell has since been found near Victoria by Dr. Newcombe.

XYLOTRYA, Leach.

125. Tylothy birinnata, Turton, sp.

Terreto bipennatu, Turtos, Conch. Dict.

126. Irlotrya fimbriata, Jefireys.

Troedo fimbriata, Jerl., Amn. Mạ. Nat. Hist., 1\&60, p. 1:26.

Both these Teredines are said by C'arpenter to oceur at lianconver Jskand. All the specimens 1 have taken so far serem to lelong to the first named species, but 1 must admit that I have given but little attention to these shells and have collected very tew specimens.

Dr. Newcombe in his catalogue records $X$. fimbriata tiom Victoriat 
on my authority, but I am afraid this is a mistake, for which I must apolocrize, as a re-examination shows that all my specimens alle $X$. bipinnata.

SCAPH()Р()1)

DENTALIUM, Limne.

127. Dhatalium indanorum, Carpenter.

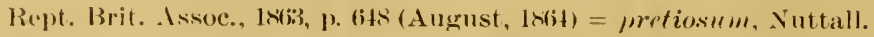

(i)mmon in om northern waters though not yet met with on the eastern or wouthern coast of I'ancouver Island,

Shells of this species were formerly of considerable value as a medium of exchange among the Indians and they are still extensively used by the aborigines for ornamental purposes. Jeftreys supposed this species to be equivalent to the British $D$. entale, Linne.

\section{Dentalium Rertius, Carpenter.}

Rept. Brit. Ansoc., 1;663, p. (its (Angust, 1864); and Proc. Acad. Nat. Sci. Phila., I8(iก, p. 5!).

This species was tirst found (deal) in Puget Sound by Kennerley, and Carpenter speaks of it as being "very rare." The only British Columbian specimen I have seen or heard of, is the one in the Geological ILuseum at Ottawa, which was dredged alive by $\mathrm{Mr}$. Richardson, near Victoria in 1875 .

CADULUS, Philippi.

129. CADtuUs aberrans, Whiteaves.

'Trans. Roy. Soc. Canmla, 1886, vol. iv., sect. iv., p. 124, tig. ㄹ.

This species was one of Dr. Dawson's discoveries. It was dredged by him in 1885, rery abundantly in Forward Inlet, Quatsino Sound, in 10.20 fathoms mud.

The shell has not no far as I know been found anywhere else in British Columbia, but Mr. Whiteaves has a note that it has been dredged near the Catalina Islands by Dr. J. G. Cooper.

\section{(iASTHLOP()I)A.}

\section{P'TEROPODA.}

It would perhaps have been better to have omitted all mention of this order as no species have been collected by recent observers, but I did not like to omit any name that has had a place on Carpenter's list 
and he gives one species of Pteropoda ats having heen collected by tant in British Columbian waters.

It is a species of wide distribution in the Atlantic as well as the Pacific Ocean and is tigmerl by Dall in pl. lxvi., tig. 113, of Bulletin 37 , U. S. Nat. Mus., previously referred to.

Carpenter" writes [130] " Cavolina telemus. Lime = Hyaleca tridentata, Forsk non Lamarck." Dall gives it as C'avolina tridentata Forsk. I am not in a position to form any opinion as to whether Linne's older name has reference to the shell in question or not.

\section{OPISTIITOBRANC'HIATA.}

\section{RICTAXIS, Dall.}

\section{Rictaxis punctoceilata, Carpenter, sp.}

Tornetelle punctorceluta, Cpr., Rept. Brit. Assoc., 186:s, p. 6t6i (Augt., Ixtif): and .Fourn. de Conch., vol. xii., p. 139 (April, 186i5).

A southern shell only recently detected in our waters. The first native specimens I have seen were dredged by Professor Macoum and myself in Departure Bay last your. I have since heard that large specimens have been found dead on the beach at the north end of Vancourer Island, by Mr. Anderson, and that others have been collected on the east sicle of Denman Island by Mr. Harvey.

\section{TORNATINA, A. Adams.}

\section{Tornatina cuicitella, Gould, sp).}

Bulle (1lievel culcitella, Gould, Bost. Journ. Nat. Hist., vol. vi., 110. 3, p. 377. pl. xiv., fig. \& (Oct., 185i3).

+ Bullu (Tomatina) cerculis, Gould, op). cit. p. 378, pl. xiv., fig. 9 (Oct.. 1s,is).

Bullina (Tormatina) eximire, Baird, Proc. Zool. Soc. L.ondon, 16itis, p. 17, pl. i., fig. 5 .

This is the commonest of our three Tornatinas. It seems to abound in about ten fathoms wherever the bottom is sandy. Dr. Dawson obtained it at the Queen Charlotte Islands and in various localities in the straits of' Georgia. Discovery Passage and Queen Charlotte and Quatsino Sounds. Dr. Newcombe has dredged it in Ganges Harbour, Clayoquot Sound and at Comox, Professor Macoun at Sooke-and I have myself found it at Victoria and Jeparture Bay.

133. Tornatina incutata. Cinlel.

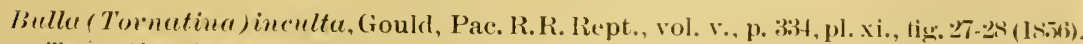
Tornutina inculta, Gould and Carpenter, Proe, Kool. Soc. I.ondon, 1s:56, 1. 21:3.

The only specimens of this species that have been taken up to the present time in British Columbia were obtained by myself by dredging in Departure Baly in 1858. 


\section{4. 'TORNaTINa HaRPa, Mall.}

Aner. olour. conch., vol. vii., p. 136, pl. xv., tign. 11 (Novembler, 1nt1).

A single specimen of this little shell was dredged, in about tive fathoms, in ('layoquot Sound last September by Dr. Newcombe. It was determined for him iy Dr. Dall. Tornatina harpa was described from Monterey, California, "Three specimens adhering to the tentacula of A.tinias."

\section{CYLICHNA, Loven.}

135. Cylichna crlindracea, Pennant, sp.

Bulla rylimelmerer, Penu., Brit. Zool., vol. ix., p. HT, pl. lxx., fig. 8.5.

val. attonsa, Cpr., Rept. Brit. Assoc., 186:3, ]) 647 (Angust, lintit); and Proc. Acad. Nit. Sci. Phila., 1865, p. 58.

= (: mopinqur, E. A. Smith, Am. Mag. Nat. Hist., series t, vol. ix., p. 335l.

This shell is not very common. It has been recorded from the Strats of Georgia, Quatsino Sound and the Queen Charlotte lslands, by Mr. Whiteaves, under the name $C$. alba. Dr. Newrombe has dredged it at Comox and Clayoquot Sound, Prof. Maxoun at Sooke, and I hare dredged it in Departure Ray.

I have seen the type of $C$. propinqua which is in the Natural llistory Museum, fouth Kensington. It is a tine specimen of $C$. attonsa.

\section{DAPHANA, BrOWH.}

\section{Diapliana peliuglia. Brown.'}

III. Reeent Conch., pl. xix., tig. 10, 41 (18:27).

= Bulla hyalina, Turton, Mag. Nat. Hist., vol. vii., p. 3533 (1*3t).

= Bulla idelilis, (ionld, Invert. Mass., ed. i., p. 164, fig. 95 (1s+1), etc., etc.

Five immature shells were found by me among roots of kelp washed ashore near Clover Point, lictoria, in $1 \S 88$. Dr. Dall, to whom these were submitted, referred them doubtfully to debilis, Gonld.

Littely I have seen a full-grown specimen taken at Sooke by Prot. Macoun, and I find it to accord exactly with the description of Utriculus hyalina in .Jeftreys's "British Conchology," and also with the figure of" Gould's Bulla debilis in the "Invertebrata of Massachusetts."

$D$. pellucida is not a very commou species in Emro ean seas. Jeffieys lak noted aloout thirty localities for it on the British coasts, and quotes it also from Norway, Sweden, Iceland and Greenland, and from Mateira and the Canary Islands.

As debilis it is on record from Listern American coasts and it is now recorded I think for the first time from the Pacific Ocean.

1 I atopt the synourmy of this species as griven by Verrill in Proc. I. S. Nit.

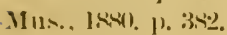


II A.INEA, reach.

137. II AMINEA HYDATS, LimUe, sp.

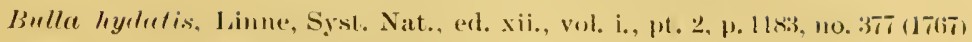
valr. vesicula, (ronld.

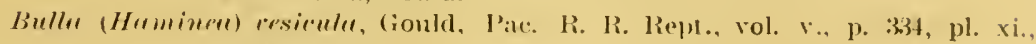
lig. 29$)(1856)$.

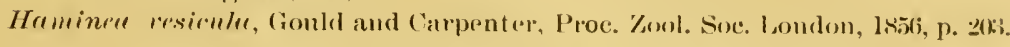

Very common indecl among sea gratss on sandy shores near low water mark.

\section{NUIDBRANT'HITA.}

No attempt is made to enmmerate the species of this order inhabiting this province as they have not been systematically collected ol studied. Carpenter mentions one species, the common Chiorcra leonina, Gould, from Puget Somnd and Whiteaves gives this and one other Dendronotus purpureus, Bergh, as collected hy l)r. Iawson in 1855.

As our species alre numerons and many of them large and conspicuous it is hoped that before long some one may be induced to undertake their collection and determination.

\section{PULMONATA.}

In order to make this calalogne more complete a list is bere giren of our British Columbian land and fresh water Pulmonata.

138. Selenites Vancouvbiknsis, Leal. sp.

139. Selent'tes spontella, Ciond. sp.

140. Limax agrestis, Limne.

141. Jimax hyprborels, Westerluml.

142. Vitrina preifreri, Neweomb.

143. IYalina arborea, Nia, sp.

144. Hyalina radiatula, Alder, sp.

145. Myalina miliun, Morse, sp.

14i. WYalina binneyana, Iorse.

147. Conelus feluves, Drapariand. sp.

148. L'ristlloma lansingi, Bland, sp.

14!. P'ristiloma stearinsir. Bland, sp.

150. Ariolimax Columbanis, fronld, sp.

151. P'Rophysaon hrimphilat, Bland d Binmey.

152. Phophysan pactficra, Cockerell.

153. Patula striatelda, Anthony. sp.

154. P'ATULA Asterisca, Ilorse.

155. Punctum minutissinum, Lea. ip.

156. Punctia conspectum, Blanil, ip. 
157. Ixsinoe 'Townsendiana, Lea, nj.

158. Mesonon Columblanus, Leal, sp.

159. Mesomin devius, fiould, sp.

160. Stenotrema germanum, (ionld, sp

161. Pupa corpulenta, Morse, sp.

162. Putra smplex, (ionll.

163. Verticio ovata, Say.

164. Ferussacia subcylindrica, Lime, sle

165. Succinea Hawkinsi, Baird.

166. Succinea Nuttal liana, Lei.

167. Succinfa Oregonensis, Lea.

168. Succineia rusticana, Gould.

169. Onchidum Carpentert, W. G. Bimey.

170. Onchidella borealis, Dill.

171. Carychium kitruum, Sily, sp.

172. Linnala stagnadis. Linne, sp.

173. I Imin.ea ampla. Mighels.

174. Limnea palustris, Miiller.

175. Limnata Adeline, Tryon.

176. Limea humils, Say.

177. Limnea Nuttalliana, Leia.

178. Physa Lord, Baird.

179. Physa grrina, Say.

180. Physa ampul lacea, Gould.

181. Physa ineterostropha, Say, sp.

182. Bulinus iypnorum, Limne, sp.

183. Planorbis anuon, Ciould.

184. Planorbis trivolvis, Niay.

185. Planorbis bicarinatus, Sily.

186. Planorbis opercularis, Gould.

187. Planorbis exacutus, Say.

188. Planorbis parvus, Say.

189. Ancylus caurinus, Cooper.

190. Axcylus Fragilis, 'Tryoll.

191. Ancylus kootaniensis, Baild.

SIPIIONARIA, Grily.

192. Siphonaria Thersites, Carpenter.

Rept. Brit. Assoc., [8633, p. 647 (Angnst, 1864); and Ant. Mag. Nat. Hist., series 3. vol. xir., p. 425 (Dere, 1864).

Common on all our coasts near high water mark on rocks and sea-weed. Dr". Dall writes (" Remarks on the genus Siphonaria," Amer. Journ. Conch., vol. vi. (1871), 1). 30, etc): 
"This species having been obtained in latitude $57^{\circ} \mathrm{N}$. is puobahly the most northern representative of the genus."

\section{C"TENOBRANGIIIATA.}

SURCUIs, $11 . \mathbb{E}$ A. Adams.

19:3. Surcula perversa, (iabl).

Proc. Cal. Acad. Nitt. Sci., 18005.

With the exception of 1 wo specimens dredged by Dr. Dawson in Queen Charlote Sound all the native specimens of this shell that I have seen have been taken near Victoria. In this locality it is not rare, having been dredged in 10 to 20 fathoms, mul, by Richardson, Newcombe, myself and others.

Adult specimens are usually much eroded.

$$
\text { DRILISA, Gray. }
$$

194. Drillata ixcisa. ('arpenter.

Rept. Brit. Assoc., 1.ti3, 1. (iñ (August, 1864); and Proc. Acad. Nat. Sci. Phila.. 1865 . p. $15 \%$.

Not common. Virago sound (Dawson), clayoquot sound (Newcombe). Dead specimens at Vesurius Bay, salt spring Island, Saanich and Victoria.

\section{Drilifa cancellata, Capenter.}

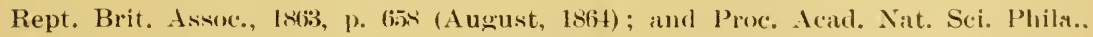
186.5, p. $(63$.

A rare species. 1)r. Kenuerley obtained a single specimen in Puget Sound, and a few have been dreelged at Victoria and Departure Bay by myself and others, and at Comox by Dr. Newcombe. This species was not represented in any of Dr. Dawson's collections.

\section{BEIA, Gray.}

Seven species of this genus are on our list, an follows:

196. Bela Fideula, (iould, sp.

Fusus fictimula, (ionld, Proc. Bost. Soc. Nat. Hist., rol. iii., p. Itl (May, 1sig) : and

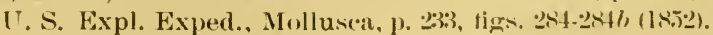

197. Bela excurvata, Carpenter.

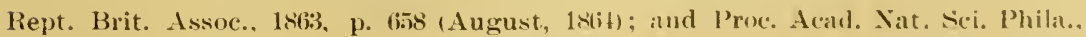
$18(i)$, p. (i3). 
198. Bela Trevelyana, 'Tluton, sp.

Penrolume Trevellenum, Tnrton, Mag. Nat. Hist., vol. vii., p. 351 (1834).

199. Bela exarata, Miiller, ipl.

Defrancia ermata, Moller. Index Moll. Gral., p. 12 (1s+2).

200. Bela crebricustata. ('arpenter, sp).

Mangilin ('rebricostata, Cpr., Rept. Brit. Assoc., 186is, 1). (iān (Angust, 1864); and Ann. Mag. Nat. Hist., series 3, vol. xv., p. 29 (.Jumary, 186io).

201. Bela tabulata, Carpenter, sp.

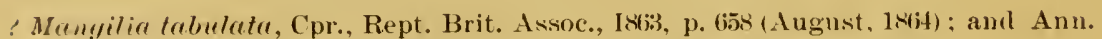
Mag. Nat. Hist., series 3, vol. xv., p. 29) (.January, $18(i$ ).

202. Bei.a violacea, Mighels and Adams, sp.

Plenewlomer riolrece, M. and Ad., Proc. Bost. Soc. Nat. Hist., wol. i., p. 50 (November, 1841); anl Bost. Jonr. Nat. Hist., vol. iv., no. i., p. öI, pl. ir., fig. 21 (January, 1842).

The first named, B̈. fidıcula, is the common species with us, and represents the European B. turricula, Montagn. It is reported from the Qucen Charlotte Islands, Queen Charlotte Sound and Johnston Straits (Dawson), and several Vanconver Island localities.

The next three species are very nearly allied to each other.

B. excurvata was described from a single specimen from Puget fiound (Kennerley).

B. Trevelyana is alded, by Mr. Whiteares. (nl the strength of one dearl shell dredgel in Viralgo Sound by Dr. Dawson.

B. exarata is the name given by Dr. Dill to shells trom Comox and Victoria sent to him by Dr. Newcombe for determination .

It seems to be just possible that our British Columbian specimens, thus variously determined, may all belong to a single species, namely that intended by Carpenter in his description of $B$. excurvata, which is said to be "like Trevelliana" and which may or may not be equivalent to Möller's eurlier B. exarata.

B. crebricostata (specimens identified by Ir. Dall) is rare at Vietoria and we have not found it elsewhere. The type specimen was collected by Swan.

B. tabulata (specimen also identified by Dall) is from Victoria, but is also on record from Queen Charlotte Sound (two specimens). Mr. Whiteaves, however, in writing of these specimens remarks "perhaps a 
ratriety of fidiculd" which makes me doubt whether he lad gentine tabulata before him.

Lastly there is $B$. violacea of which a single living specimen wan taken, according to Whiteaves. in Alert Bay by Dr. Dawson.

The two last naned species approach in form the next genus amd would not be likely to be confused with typical Belas.

MANGILIA, Risso.

We have four species:

203. Mavgilia sculpturata, Dall, sp.

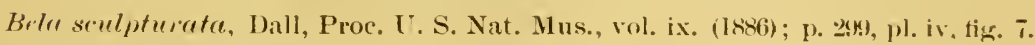

204. Mangilia angulata. Carpenter.

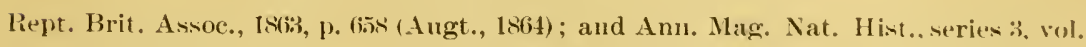
xv., p. 394 (May, 1865).

205. Mangilia interfossa. Carpenter.

Rept. Brit. Axisoc., 1863, p. (jãs (Augt., 1864) : and Ann. Mag. Nat. Hist.., sereies 3, wol. xv., p. 29 (.Jan. 1865).

2016. Mangilia levidensis, Carpenter.

Rept. Brit. Assoc., 1863, p. 65̄s (Angt., 1864); and Proc, A ad. Nat. Sci. Pliliı., 186i5, p. (63). funebrale. Dall, Amer. Journ. Con h., vol. vii., p. 100 (1871), teste Dall. Proe. U.S. Nat. Mus., vol. ix. (1886), p. 299.

The first three of these species are closely related. M. interfossa and angulata have not been detected here since Carpenter's time but sculpturata is common in nearly all the Vanconver Island localities I have examinel. It was taken also at the Queen Charlotte Islanils br Dr. Inawon. M. sculpturata is a rather variable shell and Dr. Dall tells me that northern specimens lack the colour band that is so conspicuons in our shells.

M. levidensis is a beautiful shell quite distinct fiom and consilenably" larger than the three last mentioned. It has only been found, recently. by Dr. Newcombe and myself, at Comox and Victoria. The type - jecimens of levidensis and angulata were from P'uget Sound and of interfossa trom Neeah Bay.

Dr. Newrombe has a shell apparently of the present genus which Dr. Dall has informed him is probably of an undeseribed species. Still another shell which may belong here was described by .Ir. L. A. Smith ats Pleurotoma Vancouverensis (Ann. Mag. Nat. Hist., series 5, vol. vi.. p $28 t$ (1880), but I have not seen the description and do not know the speries. 
CANCELLA RIA, Lamarck.

207. ('ancellaria mojenta. Carpenter.

Hept. Brit. Ansoce. 18663, p. 660 (Angust, 1864); and Am. Mag. Nat. Hist., series 3. vol. xr., p. 32 (.January, 1865).

208. Cancellaria Unalashoensis, Dall.

Cancelluria (Trigonoslome) Unalashlensis, Dall, Proc. Cal. Acad. Sci., rol. r., 1. 5x. pl. ii., fig. 1 (1873).

209. Cancellaria circumcincta, Dall.

Cruncelluria (Trigonostoma) (ireumcincta, Dall, Proc. Cal. Acad. Sci., vol. v., 1) 5Ł. pl. ii., tig. 2 (1873).

Here again we have three species very nearly allied, but probably distinct.

C. modesta was described from Swan's collection, and has not been since noticed in this province.

C. Unalashkensis and circumcincta were leseribed and figured by Dall, ${ }^{1}$ the first from Unalashka, where, he says, modesta also was found, and the latter from Popoff Strait, Shumagin Islands.

C. Unalashkensis has since been found at Victoria and Clayoquot Sound by Dr. Newcombe, and circumcincta has been dredged by Dawson at Forward Bay, Freshwater Bay and Cullen Harbour, and by myself in leparture Bay, near Nanaimo.

A DMETE, Möller.

210. Admete Couthouxl, Jay, sp.

Cuncellurice Couthouyi, Jay, Catalogue, ed. 3, pt. 77 (1839). $=C$. buccinoides, Conthony, 1838 (preoccupier).

= viritula, Auct., non O. Fab.

This Atlantic species was added to our list by Whiteaves, who records six specimens as having been taken at various points in Queen Charlotte Sound by Dr. Dawson. Dr. Newcombe has since taken a specimen near Victoria. Dr. Dall has pointed out (Proc. U. S. Nat. Mus., ix., 1886, p. 298) that this species is not the Tritonium viridulum of O. Fabricins, although it has long gone under that name.

OLIVFLTA, Swainson.

211. Olivella Biplicata, Sowerby, sp.

Olice biplicate, G. B. Sby., Tank. Cat., app. xxxiii, no. 2332 (18:5).

Very abundant on the north and west coasts of Vancouver Island

1"Preliminary Descriptions of New Species of Mollusca from the Coast of Alaska, with notes on some rare forms," Proc. Cal. Acad. Sci., vol. v., pp. 57-6ะ. 1). ii., April, 18:3). 
in sand between tides, and to a depth of a few fathoms below low-water mark.

\section{Olivella Betioa, Cirpenter.}

Rept. Brit. Assoc., 1863, p. (Hil (A ugust, 18664).

Very common in shallow water on sandy hottoms. Queen Charlot te Islands, Queen Charlotte Sound and other localities (Dawson): Therarture Bay, abundant (G. W. Taylor); Victorial, rare (New(ombe); Clayoquot Sound (Newcombe); Comox (Macoun).

VOLUTELLA, Swainson.

213. Volutella pyriforis, Capenter.

Rept. Brit. Assoc., 186i3, p. 661 (Angust, 1861); and Journ, de Conch., vol. xii., p. 148 (April, 1865).

A common shell usually found under stones, or uniler seaweed on rocks, near low witer mark, but sometimes dredged from deejer water. It occurs from Victoria to the Queen Charlotte Islands. During life the animal is of a bright yellow colour.

\section{MITROMORPHA, A. Adams.}

214. Mitromorpha filosa. Carpenter.

? Daphrella filosı, Cpr., Rrpt. Brit. Assoc., 18(i3), p. 6.os (August, 1sit).

Mitromorpha filosa, Cpr., Ann. Mag. Nat. Hist, series 3, vol. xr., 1) Is: (March, 18(iō).

Described from Sta. Barbara and not very rare at several other points on the Californian coast. The only British Columbian specimens I have heard of were three, dredged by Ir. Dawson at the mouth of Cumshewa Harbour in 20 fathoms of water.

215. Mitromorpha effersa, Carpenter.

? Daphnella effusa, Cpr., Rept. Brit. Assoc., 1sib3, p. li5s (August, 1s(t) ; and Ann. Mag. Nat. Hist., series 3, vol. xv., p. 29 (January, 1s(6). ).

Described from "one broken specimen, Neeah Bay, Swan," a lather" slender title I am afraid, to a place on our list.

\section{BUCCINUM, Linne.}

216. Buccinum POLARE, Griy.

Buccinum polaris, Gray, Zool. Voy. Blossom, p. 128 (1*39), var. ? perre(tssum, 1)all.

Buccinum percrassum though now thonght, by some conchologists, to he a distinct species was described as a variety of $S$. polare and it was 
under this name (though most unfortunately as var. compactum instead of percrassum) that our tirst British Columbian specimens were recorded.

Under this name (compactum) will be found a note of two specimens, lead, found by Mr. Richardson on the beach at Victoria in $\mathbf{1 8 7 5}$ and of one specimen, also dead, that was taken hy Dr. Dawson off False Hear, Vancouver Island, ten years later.

Since that date Dr. Neweombe has lredged three dead specimens off Macauley's point near Victoria, and both the doctor and myself have found fossil specimens in the Boulder Clay.

$B$. percrassum is not uncommon, living, to the north of us.

\section{Buccintal cyaneun, Bruguière.}

vir. Mqerchianum, Fincher.

Folutolurpe merchiana, Fischer, Journ. de Conch., vol. vii., p. 299 (March, 1859).

In 1590 I received from Mr. E. S. Wilkinson, four specimens of this species, that had been picked up by him on the beach at Alert Bay, Vancouver Island. One of the specimens was alive when found, the other three dead. Dr. Newcombe has since found a dead specimen on the shore at Victoria.

My shells were kindly determined for me by Dr. Dall.

CHRYSODOMUS, Swainson.

218. Chrisodonus fornicatus, O. Fabrieius, sp.

Tritonium fornicutum, O. Fab., Fauna Gronl., p. 399 (1780).

The first specimens of this speeies found here were two deat ones dredged by myself outside Victoria Harbour in 1886 . 1)r. Newcombe has since dredged a couple of living specimens in the same locality. When fresh the shell is of a dark purplish brown colour, with an olivaceous epidermis.

\section{Chrysodonus iriratus, Martyn, sp.}

Buccinum kieutum, Martyn, Univ. Conch., vol. ii., no. 43, pl. xiii. and xiv., fig. 1 (1784). decemeostatus, Midd., not Say. Iiddendorffi, Cooper.

Five living specimens of this species were dredged by Dr. Dawson, in 1s85, at Freshwater Bay, near Malcolm Island, and off False Head, all of which localities are in Queen Charlotte Sound.

I have not seen living specimens from any more southerly localities, but Dr. Newcombe has dredged dead specimens near Victoria. 
220. C'urysodomus Kenvicottit, Dill.

Buccinum Kennicottii, Dall, Amer. Journ. Conch., vol. vii., p. 108, pl. xv., tig. I (November, 1871).

Chrysorlomus Kennicottii, Dall, Proc. Cal. Acad. Sci., vol. iv., p. ำ1 (Octolver, 18т2).

A single dead specimen was dredged by me in the same place and at the same time as the specimens of $C$. fornicatus mentioned above. The species was described by Dall from Unalashka.

221. Chrysodomes tabulates, Baird.

Proc. Zool. Soc. London, 1863, p. 66, pl. i., fig. 1.

This is our most abundant species of Chrysodomus, though at present we have only found it in the southern parts of the province.

It is dredged quite commonly near Victoria, in 10-20 fathoms.

The dead shells, usually tenanted by large hermit crabs, often contain also beautiful specimens of Crepidula navicelloides.

\section{Cirrysudonus Harfordi, Stearus.}

Fusus (? Chrysodomus) Harfordi, Stearns, Proc. Cal. Acad. Sci., rol. v., p. 79 (1573).

The type specimens of $C$. Harfordi were found in Mendocino Connty, California (Harford) and the Farallones (Watkins). The single example fonnd in British Columbia was taken alive by Dr. Dawson on rocks at low water in Houston-Stewart Channel, Queen Charlotte Islands, aud is now in the museum of the Geological Survey at Ottawa. For an extended description of this speeies, see Dall "On the California species of Fusus," in Proc. Cal. Acad. Sci., vol. vii., 1877.

\section{Chrysodonus rectirostris, Carpenter.}

Rept. Brit. Assoc., 1863, p. 664 (August, 1864) ; and Proc. Acat. Nat. Sci. Phila., 186.5, p. 64 .

=sipho rungustus, E. A. Smith, Ann. Mag. Nat. Hist., series 5, vol. vi., p. 287 (1s81).

This species was deseribed by Carpenter from a single specimen taken by Kiennerley in Puget Sound. The type, which is preserved in the United States National Museum, was not in good condition, and Carpenter's original description will hardly apply to perfect specimens. Hence the species has been redescribed by Mr. E. A. Smith as Sipho angustus.

It is not a common shell. Richardson dredged three living specimens near Victoria in 1875 , Dr. Newcombe has taken one or more in the same place, and I have a single dead shell also talien near Tictoria.

My specimen was compared with Carpenter's type by Dr. Dall and with the type of angustus by MLr. E. A. Smith and myself, so that there can be no doubt as to the synonymy. 
224. Chrysonomus pheniceus, Dall.

Proc. U. S. Nat, Mus., vol. xiv., p. 187 (1891).

This species was taken by the naturalists of the U.S. Fish Commission steamer Albatross, near Goletas Channel, Queen C'harlotte Sound.

225. Chrysodonus Verkruzeni, Kobelt.

One large dead shell belonging to this species was dredged by $\mathrm{Dr}$. Dawson off False Head, Vancouver Island, in about thirty fathoms, this being, according to Mr. Whiteaves, the most southerly locality yet reported for the species.

MOHNIA, Friele.

226. Mohnia Frielei, Dall.

Proc. U. S. Nat. Mus., vol. xiv., p. 187 (1891).

Off north coast of Vancouver Island, $1888^{\circ}$ (Albatross).

EUTHRIA, Gray.

227. Euthria dira, Reere, sp.

Burcinum dirum, Rre., Conch. Icon., Mon. of Bucc., fig. 92 (December, 1846). = Fusus incisus, Gould (1849).

= Tritonium (Fusus) sitchense, Midd. (1849).

A common littoral species, oceurring in all localities examined within the province, and ranging northward to Alaska and southward to Monterey.

Specimens of Crepidula adinca are commonly found attached to the shells of this species.

NASsA, Lamarck.

228. Nassa rossata, Gould, sp.

Buccinum fossatum, Gould, Proc. Bost. Soc. Nat. Hist., vol. iii., p. 152 (Ja1., 1850) : and U. S. Expl. Exped., Mollusca, p. 254, fig. 321, 321a (1852).

This species oceurs with us only on the west coast of Vancouver Island; it is found from extreme low water to twenty fathoms.

It is a not uncommon Californian shell.

229. Nassa ilendica, Gould.

Proc. Bost. Soc. Nat. Hist,, vol. iii., p. 155 (January, 1850) ; and U. S. Expl. Exped.. Mollusca, p. 263, figs. 331, 331a (185\%).

Very abundart and variable. It has been dredged, wherever dredging has been carried on, from the Queen Charlotte lslands to Victoria. A 
valiety that was named $N$. Gibbsii by W. Cooper is the common form between tides in Esquimalt harbour.

As'TYRIS, H. and A. Adams.

\section{Astrris tuberosa, Carpenter: sp.}

Amygla tuberose, Cpr., Rept. Brit. Assoc., 18633, p. 6662 (August, 1864); and Amn. Mag.

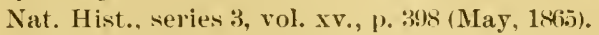

Dr. Carpenter, on 1) 628 of his "Supllementary Roport," writes of the present species as "lare" among Swan's Puget sound and Vancouver Island shells, and on page 662 of the same report he places it in the Vanconver column.

In his description of this species, howerer, in the Annals and Magazine of Natural Ifistory, he makes no mention of any locality for the shell north of Monterer. Perhaps the name should be struck off our lists, for the species does not seem to have been found in the province since Carpenter's time.

231. Astyris carinata, ITinds, sl'.

Cotumbella ererincrtu. Hinds, Zool. Voy. Sulph., vol. ii., p. 39, pl. x., tigs. 15-16 (1E4t). $=$ C. gausapata, Gonld, 1850 .

$=$ C. Hindsii, Reeve.

C. gausapata is the northern form of carinata. The species is common, and is found between tides or just below low-water mark all through the province. Dr. Newcombe, in his Catalogue, confuses this species with the next, which is, as far as I can see, undoubtedly distinct.

NITIDELLA, Swainson.

232. Nitidella Gouldir, Gould and Cpr.

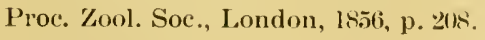

This is a much larger shell than the last named, and is further dis. tinguished by the possession of a thick and rough epidermis. It is generally obtained by dredging in ten to twenty fathoms, and has been taken by myself and others abundantly at Victoria and Departure Bay ; also on the west coast of Vancouver Island, by Dr. Newcombe, and in many northern localities by Ir. Dawson.

Tryon included this species in the synonymy of Astyris carinata, and Dr. Dall has also expressed the opinion that they belong together. I still think, however, that the species are distinct, as I have seen 10 approach to an intermediate specimen.

Mr. E. A. Snith has redescribed this shell under the name Colum. 
bella (Nitidella) Dalli. I have compared some of our shells with S'mith's type and find no difference whatsoever.

AMPHISSA, H. and A. Adams.

233. Amphissa corrugata, Reeve, sp.

Burinum iorrugatum, Rve., Conch. Icon., Mon. of Bucc., no. 110 (February, 1s47).

Common both between tides and in leeper water.

The littoral specimens are usually much overgrown with Polyzoa. There is a variety that is smaller than the ordinary form, and which in some respects approaches $A$. versicolor, Dall, and $A$. undata, $\mathrm{Cpr}$. It is, however, I believe, only a variety of $A$. corrugata The specimens recorded by $\mathrm{Mr}$. Whiteaves as $A$. versicolor, from Houston-Stewart Channel and Cumshewa Harbour (Queen Charlotte Islands), should most probably be referred to this form.

\section{TROPHON, De Montfort.}

\section{Trophon multicostatus, Eschscholtz, sp.}

Murex multicostatus, Esch., Zool. Atlas, pt. ㄹ, p. 11, pl. ix., tig. 4 (1829).

I have retained for this species its familiar west coast name, though there is little doubt but that our shell is a form of the European Trophon clathratus, Linne, sp. (Syst. Nat., ed. xii., vol. i., pt. 1, p. 1223, no. 563, 1767). The species occurs here in two forms, the ordinary one with the interior of the shell white, and a rarer one with the month dark chocolate colour. I have secn a specimen of this form in the Natural History MLuseum, South Keusington, labelled as a distinct species, but Dr. Dall, who has seen one of my specimeus, regards it as merely a variety of $T$. multicrstatus. This species occurs not uncommonly at Victoria, and it was taken by Dr. Dawson in Queen Charlotte Sound and Johnston Straits, but not at the Queen Charlotte Islands.

235. Trophon Orpheus, fiould, sp.

Fusus Orpheres, Gould, Proc. Bost. Soc. Nat. Hist., vol. iii., p. 142 (May, 1849); and U. S. Expl. Experl., Mollusca, p. 234, fig. 285-28.̄в (185²).

This species, according to Dr. Newcombe, is the most abundant Trophon at Victoria. It has also been taken by Dr. Neweombe at Departure Bay, and possibly by Dr. Dawson in Cumshewa Harbour. Mr. Whiteaves gives it from three localities in Queen Charlotte Sound, but he has evidently confused this species with the next, and I believe all the specimens in Dr. Dawson's collections should be included under $T$. Stuarti.

1 Annals and Magazine of Natural History, series 5, vol. vi., p. 2it (1R*0). 
236. Trophon Stuakti, E. A. Smith.

Proc. Zool. Soc. Londlon, 1880, p. 481, pl. xlviii, fig. 1 .

This is our largest and tinest species of Trophon. It is perfectly distinct from $T$. Orpheus and very much larger. The type was dredgerl by Capt. Vidler near Victoria, and passed into the hands of a London clealer, from whom Mr. Smith obtained it.

It is apparently much rarer than Orpheus, and has so fin only heen found at Victoria by Capt. Vidler, Dr. Newcombe and myself, and by Dr. Dawson at the three localities in Queen Charlotte Sound referred to nnder the preceding species. Dr. Dawson's specimens were threw in number and very fine.

237. Trophon trandsculpus, Carpenter.

Ann. Mag. Nat. Hist., series 3, vol. xvii., p. 27i (April, 1si6i).

Not rare, occurring everywhere from Victorial to the (sucen Charlotte Islands in 10-30 fathoms.

This species was described by Carpenter as a Pleistocene fossil from Sta. Barbara, California.

238. Trophon Daliti, Kiobelt.

Mon. of Trophon in Mart. Chem. (nem. iusg.)

T. muriciformis, Dall, ${ }^{1}$ Proc. Cal. Acad. Sci, vol, vii. (1九ī).

Dall's name being preoceupied, it was changed by liobelt as above.

The species was described from Icy Cape and Bering Fica, but has been dredged near Victoria by Richardson, Newcombe and myself. It seems to be very rare, and only a few specimens in all have as yet been obtained.

Trophon Dallii is well figured in plate iv., figure 6 , of volume ix.. of the Proceedings of United States National Museum.

OCINEBRA, Leach.

239. Ocinebra lurida, Middendorti, sp.

Tritonium (Fusus) luridum, Midd., Bull. Acad. Sci. St. Peters.. vol. vii., no. 16u, p. 244 (1849) ; Mal. Ross., pt. 2 , p. 150, no. 15, pl. iv., figs. 4 and .5 (18't9).

= ritularia aspera, Baird, Proc. Zool. Soc. London, 1:6i:, p. (ki. pl. i., fig. 2.

I The paper in which this species was first described is entitled " preliminary description of new species of Mollnsks from the northwest coast of Americil " (Proce. Cal. Acad. Sci., vol, vii., March, 1877). It contains also the original lescription of another of our shells, Kemerlia yrandis. 
240. Ocinebra interfossa. Carpenter.

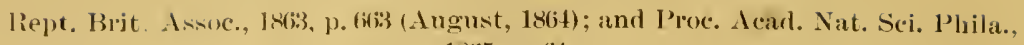
$18(i 5)$, p. (i.4.

Buth the above are common littoral shells, occurring all through the-province under stones, near low water mark. Botlu are subject to considerable variation.

CHROSTOMA, Conrad.

241. Cerostoma foliatum, Martyn, sp.

Prrpura foliata, Martyn, lnis. Conch., vol, ii., no, 66, pl. xxir., fig. 1 (1784).

= Murece fotirtus, Gmelin.

M. monortom, Esclr., etc., etc.

At extreme low tide on all on rocky coasts.

PURPURA, Bruguière.

242. Plrpura crispata, Chemnitz, sp.

Bueriumu roispatum, Chen., Mart. Conch. Cab., vol. xi., p. 84, pl. 187, figs. 1802, 18(0:3 (1795).

M. Lartuce and M. forruginems, Esch. (18:9)). etc., etc.

243. PURPURA Lima, Martyn, sp.

Burrin um fime, Mart., Univ. Conch., vol. ii., mo. 46, pl, xv., fig. 1 (1784).

- erureliculatre, Durclos (183:2).

- dremromtreta. Midrl. (1849).

244. Purpura saxicola, Valenciennes.

Zool. Voy. Venus, pl. viii., fig. 4 and ta (1846).

These threespecies of Purpura are all common on rocks between ticles and here at any rate are quite distinct from one another in all their varieties.

From some few localities these shells are absent without any apparent cause. For instance. during three days shore collecting at Nanaimo last year. I did not see a single specimen of either lima or saxicola and only in one spot a few specimens of crispata.

There are conchologists who would place all these species under one name and there are others who would consider even this a synonym of the Purpura lapillus of the Atlantic. Many varieties of $P$. saxicola have been honoured with separate names, which however are hardly worth preserving. 
SCAIA. Humphrey.

245. Scala Indinorum. Carpenter, sp.

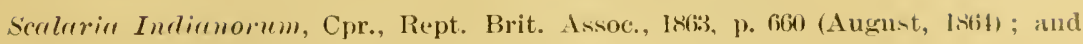
Anı. Mag. Nat. Hist., series 3, vol. xv., p. 31 (.Tamary, Istis).

This species is not rery abmulant. It has been dredged at Depallture Bay, Baynes Sound and Comox. at Discovery Passage, and at the Queen Charlotte Islands, but has not yet been found at Victoria.

The type specimens were from Swan's collections from Neeah Bay.

OPALIA. II. \& A. Adams.

246. Opalia borealis; Carpenter.

Rept. Brit. Assoc., 1863;, p. 660) (Angust, 1864); and Ann. Mag. Nat. Ifist., series 3, vol. $x$ v., p. 31 (.January, 18(65)

Found by the United States Exploring Expedition in Puget Sound and indicated, but not described, by Gould in Expl. Exped. Mollusca, p. 207. The shell was obtained also by kwan at Neeah Bay and Tatooche Island.

In British Columbia I have nerer found $O$. borealis alive, but hare many times received the dead shells from rarious points on the west coast of Vancourer Island. Dr. Newcombe has been more fortunate than I hare and has taken living specimens at Clayoquot Sound. Professor Macoun found a few very large dead specimens at Sooke.

EULIMA, Risso.

247. Eulina micans, Carpenter.

Rept. Brit. Assoc., 1863, p. 659 (Angust, 1864) : and Proc. Acad. Nat. S(ci. I'hilit, 1865, p. 633 .

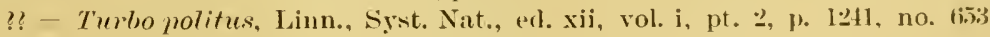
(ii 67 ).

This species is probably, but not certainly, the same as the $E$. polita of Emrope. For the present therefore the name applied by Carpenter to the western shell is retained. The species is widely distributed in our seas and in some localities is rather common.

It has been dredged at Victoria, Departure Bay, Comox and Clayoquot and at numerous points in Queen Charlotte Sound, the straits of Georgia. Johnston Straits and at the Queen Charlotte Islands.

It is usually found in sand at a depth of 10 to 40 fathoms.

248. Eulima sp.

A second sprecies of Eulima is recorded by Whiteares, under the name "Eulima incurva, Renieri $=E$. distorta, Auct," as having heen 
dredged by Dr. Dawson in the Straits of Georgia, Forward Bay and Alert Bay and as occurring between tides in Discovery Passage and Goletas Channel. I have found specimens of the same shell at Victoria and Departure Bay both between tides and by dredging, and Dr. Newcombe has specimens from C'latyoquot Sound:

lienieri I believe only published the name withont any description, and as our shell does not appear to be the same as the $E$. distorta, Deshayes, of English conchologists, I am not sure that it has at present any proper name.

TURBONHLLA, Risso.

249. Turbonilia tridentata, Carpenter, sp.

Chemnitzia trirlentata, Cpr., Rept. Brit. Assoc., 1863, p. 659 (Augnst, 1N(if) ; aud Journ, de Conch., vol. xii., p. 147 (April, 1865).

This species was described from Puget Sound (Kennerley) and from Sita. Barbara, Monterey and San Pedro. It has not been found in our waters by recent collectors.

250. Turbonilla Lordr, E. A. Śmith, sp.

Chemnitzin Lorti, E. A. S., Ann. Mag. Nat. Hist, series 5, vol. ri., p. 2k8 (1s80).

A rery few specimens of this species have heen dredged by Dr. Newcombe and myself in Departure Bay. I have compared some of these with Mr. Smith's types. This is the largest speeies of Turbonilla found in British Columbia.

\section{Turbonilla torquita, Grould, sp.}

Chemnitzin torqueta, Gould, Bost. Journ. Nat. Hist., vol. vi., no. 3, p. 3\&4, pl. xiv., fig. 16 (October, 1253 ).

= $\therefore$ Vunrouverensis, Baird, Proc. Zool. Soc. I.ondon, 1863, p. 67, pl. i., fig. 3.

252. Turbonilla chocolata, Carpenter; sp.

Chrmmitzin rhocolata, Cpr., Rept. Brit. Assoc., 1863, p. (i59 (August, 1864) ; and Proc. Cal. Acad. Nat. Sci, vol, iii. (1866).

These two species are I think equally common. T. chocolata has been dredged at Victoria, Departure Bay and Clayoquot Sound. T. toryuata, at the two tirst named places and also at Duncan Bay, Forward Bay and Cullen Harbour (Vancouver Island). Doubtless both species will be found in other localities when search is made. In Calitornia $T$. tor. quata is said to oceur abundantly on the shells of Haliotis (Orentt). 
ODOsTOMIA, Fleming.

253. Odestoula vucifuruts, C'arpenter, and var, arellana, Carpenter.

Rept. Brit. Assoc., 1863, p. (6.5s (August, 1864); and Ann. Mag. Nat. Hist., - veries.3, vol. $x{ }^{2}$, 1). 30 (January, 1865).

\section{Odostomia satura, Cirpenter, and var, gortodr, Carpenter.}

Rept. Brit. Assoc., 180:3, p. (65) (August, 1864); and Amm. Mag. Nat. Hist., series :3, vol. $\mathrm{xv}, \mathrm{p.} 30$ (January, 1865$)$.

255. Opustonita inflata, Carpenter.

Rept. Brit. Assoc., 1863, p. 65̃s (Angust, 1864); and Anu. Mag. Nat. Hist., series 3, rol. xv., p. 395 (May, 186.5).

256. Odostomia tenulsculpta, Carpenter.

Rept. Brit. Assoc., 1863, p. 629 (August, 1864); and Amm. Mag. Nat. Hist., serie .: vol. xv., p. 30 (.January, 1865).

25\%. Odostomia stranine., Cirpenter.

Rept. Brit. Assoc., 1863, p. 659 (August, 1864), and Journ. de Conch., vol. xii., p. 146 (April, 186.5).

258. Odostonla Sitrensis, Dall.

259. Odostonta gRariuA, fiould.

Bost. Journ. Nat. Hist., rol. vi., no. 3, p. 384, pl. xir., fig. 14 (Oetoler. 123̄is).

The Odostomias of British Columbia have not yet been satisfictorily worked up. Specimens are very common both between tides and among dredged material, and I have accumulated many hundred shells. I have never yet, however, had an opportunity of either critically examining these myself or sulmitting them to competent authority and therefore cannot write with confidence upon the subject.

Of the seven species enumerated ahove, two, O. inflata and O. tenuisculpta, are quoted on the strength of specimens collected by siran in Puget Sounil.

A thiml, O. Sitkensis, is recorded by Whiteares from the queen Charlotte Islands and False Bay, Lasqueti Island; this species and O. straminea being apparently the only ones met with hy Dr. Iilwson.

The other four species are in my own collection.

$O$. satura, or the shell that I think to lee this species, is the common large torm in Departure Bay.

$O$. nuciformis, which is the most easily reeognized of our species 
(fiom its large size and Tornatelloid shape) occurs larely under stones at low tide at Victoria, Esquimalt, Salt spring Island, Nanaimo, etc. I have never found more than one or two specimens of this species together.

$O$. gravida and $O$. straminea are smaller shells and have been dredged in rarious localities round Vancouver Island, and a single specimen of the last named was talien at the Queen Charlotte Islands by Dr. Dawson.

There are three or four other forms for which I have not yet been able to find satisfactory names, and 1 am inclined to the opinion that they belong to undeseribed species.

\section{Tritonili, Cnvier.}

260. 'Tritonium oregonense, Redtield, sl.

Tritum Oregonense, Redf., Ann. Lye. Nat. Hist. N.Y., vol. iv., no. 5, p. 16.5, pl. xi., fig. $2 a$ and $2 b(1846)$.

$=T$. rancellatum, Midd. and others, but not of Lamarck.

This species is very common at Victoria from low water mark to twenty or thirty fathoms. The dead shells often contain beautiful specimens of Crepidula navicelloides, and on one occasion, as mentioned on page 23 above, I dredged a living specimen with a colony of some twenty or thirty specimens of $T$. unquicula attached to its hairy epidermis.

I have not found this species at Nanaimo, but it appears again firther to the north, having been taken by Dr. Dawson both at low water and by dredging in Johnston and Broughton Straits, in Goletas Chamnel, and at the Queen Charlotte Islands.

Mr. Whiteaves in his paper in these Transactions (rol. ir., 1886), writes that this species is possibly only a local variety of the South American $T$. cancellatum, of Lamarck, but Dr. Dall in the 'Proceedings of the United States National Museum ' for the same year ${ }^{1}$ (1886, p. 213) has shown that the two species are quite distinct and in their geographical range widely separated.

TRIFORIS, Deshayes.

261. Triforis adversa, Montagu, sp.

Muree relleersus, Mont.

This is recorded by Carpenter as being in Swan's Neeah Bay col-

1 "Contributions to the Natural History of the Commander Islands, No. 6." This paper contains many valuable notes on the northern distribution of our shells. The following species are quuted from Bering Island in addition to others alrealy referred to in note under Penitella penita above:-Pecten Alaskensis? Placun"nomia maciochisma, Morliolaria laevigata, Cuspidaria pretinata, Siphonaria Thersites, Bela riolacea, Buccinum percressum, Tritonium Oregonense, Nruticu strusa, demere patina. solariella varicuse, and Lepirloplewens concelletus. 
lections. He remarks of this and the next species, "Rare, no differencen have been detected on comparing the Herm (British) and Neeah Bay specimens."

$T$. adversa does not appear to have been noticed here by recent collectors.

Dr. Gwyn Jeffieys considered this species to be equivalent to the Mediterranean form, = perversum, Jinne, but Forbes and Hanley considered the two to be distmnet.

CERITHIOPsis, Forbes and Hanley.

262. Cerithiol'sis tuberculata (Montagu) Carpeinter.

? Murex tuberculuris, Mont., Test. Brit., p. 270 (18013).

This is another species from Swan's collection.

Carpenter considered it identical with the English shell, but Jeffreys (Brit. Conch., ir., 268) says that it is not the same. Dr. Dawson took it at Dolomite Narrows and in Virago Sound (at the latter place in 8-15 fathoms), and I have found it under stomes at low tide near Victoria.

\section{2li3. ('erithiopsis yunita, Carpenter.}

Rept. Brit. Assoc., 1\$63), p. 640 (August, 1864); and Ann. Mag. Nat Hist., serien 3. vol. xv., p. 32 (January, 1865).

264. Cerithiopsis columa, Carpenter.

Rept. Brit. Assoc., 1863, p. 660 (August, 1864); and Ann. Mag. Nat. Hist., serien :3. vol. $\mathrm{xv}$, p. 32 (January, 1865).

Both of these species were first found hy Swan at Neeall Bay. They are evidently rare with us, a very few specimens only having been found near Victoria.

\section{BITTIUM, Leach.}

\section{Bittiun filosun, frould, sp.}

Cerithium filosum, Gould, Proc. Bost. Soc. Nat. Hist., vol. iii., p. 120) (May, 184!); and U. S. Expl. Exped., Mollusea, p. 149, fig. 175,-175e (1852).

Var. esuriens, Cpr., Rept. Brit. Assoc, 1863, p. (650 (August, 1864) : An1. Mag. Nat. Hist., series 3, vol. xv., p. 181 (Mar(h, 1865); and Journ. de Conclı., rol. xii., p. 142 (April, 1665).

Very common everywhere between tides. The common form lias the mouth of the shell purplish or ehocolate coloured within, but specimens from Clayoquot Sound and a few collected at Salt Spring Istand. are pure white. 
266. Bittium armllatum, Carpenter.

Rept. Brit. Assoc., 18633, p. 655 (August, 1864); and Ann. Mag. Nat. Hist.. series :3, vol. xvii., p. 276 (April, 1866).

Not lare among sponges in rock pools and under stones between tile marks, near Victoria. It is not uncommon in California.

TRICHOTROPIS, Broderij) and Sowerby.

267. Trichotropis canceliata, Hinds.

Proc. Zool. Soc., London, 184:3, p. 17; and Zool. Voy. Sulplı, rol. ii.. p. 39, pl. xi., fig. 11 and 12 (1844).

This shell has been dredged not rarely at Victoria, Dejarture Bay and Comox, in 10-30 fathoms, and at a greater depth. Dr. Dawson procured it at the Queen Charlotte Islands, in the Straits of Georgia, (zueen Charlotte Sound, and in most of the localities in which he collected in 1885. Dr. Jeffireys (Brit. Conch., ir., 248) places T. cancellata. in the synonymy of $T$. borealis, Brod. and Sby.

\section{Trichotropis ineris. Hinds.}

Proc. Zool. Soc. London, 1843, p. 18; and Zool. Voy. Sulplı., rol. ii., p. 40. pl. xi., figs. 13 and 14 (1844).

We have never found any shells that could lie referred to this species, which is on our list on the strength of a few specimens eollected liy Swan at Neeah Bay.

\section{CÆCUM, Fleming.}

269. C.ecum crebricinctum, ('arpenter.

Rept. Brit. Assoc., 18633, p. 655 (Angust, 1864); and Proc. Cal. Acad. Sci., vol, iii. (1866).

This little shell has only been once found in British Columbia, and then but a single dead specimen. This was obtained by Dr. Dawson at Dolonite Narrows in $187 \mathrm{~S}$.

$$
\text { BIVONIA, Gray. }
$$

270. Bivonia compacta, Carpentel.

Rept. Brit. Assoc., 186:3, p. 654 (August, 1864) ; and Ann. Mag. Nat. Hist., series :3, rol. xir., p. $4 \cdot 27$ (December, 1864).

B. compacta is generally found upon shells of Pachypoma incequale, sal appears to have a range coextensive with that of that species.

Dr. Dawson, however, found it at Discovery Passage on Trophon tenuisculptus, and at Quatsino Sound on Pecten hastatus. 


$$
\text { MESALIA, Gray. }
$$

271. Mesalia reticulata, Mighels and Adams, s]"

Truritella reticulata, M. \& A., Proc. Bost. Soc. Nat. Hist., rol. i., p. 50 (Noveuber, 1811); and Bost. Jour. Nat. Hist., rol. iv., no. 1, p. 50, pl. iv., fig. 19 (January, 1ㄴ2). $=1$. lactca, Möller (1842).

= M. lacteola, Cpr. (1864).

A very common shell in sand in ten to thirty fathoms. It has been flredged in nearly all the localities where dredging has been carried on, from Victoria to the Queen Charlotte Islands.

LITTORINA, Ferussac.

\section{Litrorina sitchana, Philippi.}

Proc. Zool. Soc. London, 1845, p. 140.

This shell is most probably only a form of the Atlantic L. rudis, and if so has an extensive range and also a very extensive synonymy.

It is an abundant and variable littoral shell oecurring throughout our province.

\section{Littorina scutulata, Gould.}

l'roc. Bost. Soc. Nat. Hist., vol. iii., p. 83 (Marcl. 1849); and I. S. Expl. Exped., Mollusca, p. 200 , figs. $241,241 a(1852)$. coasts.

Quite as abundant as L. sitchana, and occurring with it on all our

\section{LACUNA, Turton.}

\section{Lacuna vincta, Montagu, sp.}

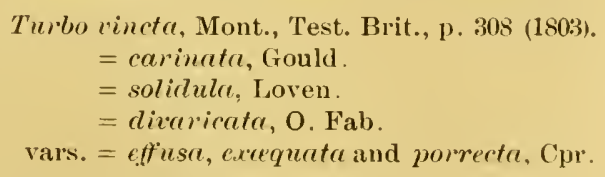

'This is a very variable shell oceurring on Znstera at low water on all our coasts.

\section{Lacuna variegata, Carpenter.}

Rept. Brit. Assoc., 1863, p. 656 (Angust, 1861); and Ann. Mag. Nat. Hist., series 3. vol. xiv., p. 428 (December, 1864).

This species occurs with the last named at Victoria and Samich, lut is not so common as is $L$. vincta.

L. variegata has not been noticed so far in other parts of the province, though no doubt it will be found when more carefully looked for. 


\section{ISAPIS, H. \& A. Adams. \\ 276. Isapis fenestrata, Carpenter.}

Rept. 13ril. Ansoc., 1863, p. 6.56 (Angust, 1864); and Ann. Mag. Nat. Hist., series 3, vol. xiv., p. 429 (December, 1864).

This species was "very rare" in swan's collection from Neeah Bay. It has not been found since except at Clayoquot Sound, where a few specimens were obtained last year in shallow water by Dr. Newcombe.

ALVANIA, Risso.

277. Alvania conpacta, Carpenter, sp.

Risson compuetr, Cpr., Rept. Brit. Assoc., 1863, p. 6506 (August, 1864); and Proc. Acad. Nat. Sci. Phila., 1865, p. (i:2.

278. Alvania filosa, Carpenter.

Rept. Brit. Assoc., 1863, p. 656 (August, 1864); and Ann. Mag. Nat. Hist., series 3, vol. $x v .$, p. 28 (.Jannary, 1865).

279. Alvania reticulata, Carpenter.

Rept. Brit. Assoc., 1863. p. 656 (August, 1864); and Ann. Mag. Nat. Hist., series 3, vol. xiv., p. 429 (December, 1864).

280. Alvania castanea, Möller, sp.

Rissou castunea, Möller, Index Moll. Groenl., p. 9 (1842).

Our four species of Alvania are found under stones, or at the bases of sponges, at low water, but from their small size are easily overlooked.

I have found the first three on many occasions at Victoria, Salt Spring Island and Nanaimo.

Dr. Dawson obtained a few specimens of compacta and reticulata at the Queen Charlotte Islands, the former species at Dolomite Narrows, and the latter in Virago Sound.

A. castanea is known from this province by a single specimen taken by Dr. Newcombe, in Clayoquot Sound. This species seems to be intermediate, as to sculpture, between $A$. filosa and $A$. reticulata.

BARLEEIA. Clark.

281. BarleEia haliotiphila, Carpenter.

Rept. Brit. Assoc., 1863, p. 656 (August, 1864) ; and Journ. de Conch., rol. xii., p. 144 (April, 1865).

Common among corallines in tide pools near Victoria and probably all along the coast.

The single specimen dredged by Dr. Dawson in Freshwater Bay, 
Queen Charlotte Sound, and recorded by Mr. Whiteaves as B. subtemuis, was most likely of the present species. B. subtenuis is common to the south of us and is distinguished by being wider and altogether much larger than $B$. haliotiphila.

HYDROBIA, Hartmann.

282. Hydrobia Californica, Tryon.

Amer. Journ. Conch., vol. i., p. 221, pl. xxii., fig. 11 (1865).

Very common under stones between tides in brackish water in the Victoria Arm and in Ganges Harbour, Salt Spring Island.

PALUDINELIıA, Pfeiffer.

283. Paludinelia castanea, Cimpenter.

Paludinella sp., Cpr., Rept. Brit. Assoc., 1863, p. 656 (August, 1864).

Paludinella castanca, Cpr., Ann. Mag. Nat. Hist., series 3, vol. xv., p. 28 (January, 1865).

Of this species Swan obtained a single specimen at Neeah Bay.

ASSIMINIA, Leach.

284. Assiminia subrotundata, Carpenter.

Rept. Brit. Assoc., 1863, p. 656 (August, 1864); and Ann. Mag. Nat. Hist., series 3, vol. xv., p. 28 (January, 1865̄).

This species like the last is known only by the single specimen obtained by Swan at Neeah Bay.

Two freshwater species will follow here,-

285. Fluminicola Nuttalliana, Lea., sp.

286. Valvata virens, Tryon.

GALERUS, Humphrey.

287. Galerus fastigiatus, Gould, sp.

Calyptrcece fastigiata, Gould, Proc. Bost. Soc. Nat. Hist., vol. ii., p. 161 (Aug., 1816) ; and U. S. Expl. Exped., Mollusca, p. 379, figs. $181481 \mathrm{~b}$ (1852).

Very common; attached to stones and dead shells in ten to twenty fathoms all round the coast to the Queen Charlotte Islands. It is probable that our shell is the same as the Galerus mammillaris, Broderip.

Sec. IV. 1895. 6. 
CREPIDULA, Lamarck.

288. Crepidula dorsata, Broclerip, sp.

Calyptrace dorsata, Brod., Proc. Zool. Soc. London, 1834, p. 38; and Trans. Zool. Soc. London, vol. i., p. 202, no. 20, pl. xxviii, fig. 10.

This species is common in sereral varieties.

Sometimes the shell is internally of a rich purple. This form is usually found on shells of Ostrea lurida.

Another variety is white streaked and spotted with brown or sometimes wholly white. This is found attached to shells and stones dredged from deeper water and also occasionally between tides on the under sides of rocks, or on dead bivalves, or in the disused burrows of Penitella penita.

\section{Crepidula adunca, G. B. Sowerby.}

Tankerville Cat., app. rii., no. 828 (1825).

This is a eommon littoral species. Near Victoria it is generally found attached to shells of Euthria dira and Calliostoma costatum. On the west coast Dr. Newcombe found its station to be on Phorcus pulligo, while in California, according to Oreutt, it is usually attached to shells of Norrisia norrisii. Dr. Dawson found $C$. adunca in Queen Charlotte Sound and at the Queen Charlotte Islands.

\section{Crepidula navicelloides, Nuttall.}

Common and variable. A large, rough form beantifully marked inside with green and purple is not uncommon on the rocks at Esquimalt. Another form of a pure white, is found under stones between tides on all our coasts. A third variety occurs in dead bivalves dredged at various depths, and a fourth is in dead Gasteropoda, e.g., Calliostoma, Tritonium, and many others,

AMALTHEA, Schumacher.

\section{Amalthea cranioides, Carpenter, sp.}

Hipponyx cranioides, Cpr., Rept. Brit. Assoc., 1863. p. 654 (August, 1864); and Ann. Mag. Nat. Hist., series 3, vol. xiv., p. 427 (Becember, 1864).

This is a rare shell on the east coast of Vancouver Island but apparently more common on the west, as I have seen many dead shells brought thence by the Indians.

Dr. Dawson found one living specimen at the Queen Charlotte Islands, and I have myself found it, but only once at Victoria. 
NATICA, Lamarek.

292. Natica clausa, Broderip and sowerby.

\%ool. Foll11.. vol. iv., pt. 15, p. 372 (1829); and \%ool. Voy. Blosisom, p. 136, pl. xxxiv., tig. 3. and pl. xxxvii., tig. fi (1839).

Not a very common species but found in nearly all localities in which dredging has been carried on.

Most of my specimens were dredged in about twenty fathoms in Departure Bity. The adult shell is nearly unicolorous, but the young are prettily marked with dark stripes. Dr. Newcombe has found this species fossil in the boulder clay.

\section{LUNATIA. Gray. \\ 293. Lunatia Lewisir, Gould: sp.}

Nretira Lentisii, Gould. Proc. Bost. Soc. Nat. Hist., vol. ii., p. 2349 (.July, 1847); and U. S. Expl. Exped., Mollusca, p. 221, fig. 253 and 253a (1852).

Common at and above low water mark. burrowing in the sand as the tide recedes. The amnular egg ribbons of this species are frequently seen on the beaches and are very puzzling to those who are macruainted with their true nature.

294. Lunatia Pallida, Broderip and Sowerby, sp.

Nertica prellide, Br. \& Sby., Zool. Journ., vol. iv., pt. 15, p. 372 (1829); and /sool. Voy. Blosson, p. 136, pl. xxxir, fig. 15 (1839).

L. reverina and L. soluta, Gould.

Not rare in ten to forty fithoms at Victoria and Departure Bay. Dr. Newcombe records it from Comox, and Dr. Dawson from Queen Charlotte Sound. This species may easily be distinguished from the young of $L$. Lewisi, by the shape of the whorls and by its much smaller umbilicus.

\section{LAMliLLARIA, Montigu. \\ 295. Lamellaria Stearnsit, Dall.}

Amer. Journ. Conch., vol. vii, p. 12.2., pl. xv., figs. 2., 3 and 6 (November, 1811 ).

L. Mepressu, Dall, MS. 1866 .

I have only two notes of the oceurrence of this shell in our waters. One dead specimen was drelged in Houston-Stewart Channel (Q. C.I.), in tifteen to twenty fithoms by Dr. Dawson in 1878 , and a second example was obtained by Dr. Newcombe in Claýoquot Sound last summer. The original (type) specimens were found dead on the beach at Monterey. 
VELUTINA, Fleming.

\section{Veletina inigigata (Limn.) Auct.}

This shell has long grone under the above name but, as many authors lave prointed out, it cannot be the Helix lavigata of Linne [Syst. Nat, ed. xii, vol. 1, pt. 2, p. 1250, no. 709 (1767)] the description of which is yuite inapplicable to our shell. Jetfreys (Brit. Couch., vol. iv., p. 242) retains the familiar name but quotes Pennant (Brit. Zool., vol. iv., p. 141, jl. lxxxvi., fig. 139) as the anthority, his description and figure being in accord with the shell in question.

Several American conchologists have used the name haliotoides, O. lab., but though the species under consideration is no doubt the haliotrides of Fabricius, it is not the haliotoides of Minller or of Linne, both earlier in date than Fabricius. (Jeffreys.)

$V$. levigata, if we may continue for the present to call it by this name, is not uncommon, attached to stones and shells dredged in ten to thirty fathoms. It has been found at Victoria, Departure Bay, Comox, ('layoquot Sound (Dr. Newcombe) and Discovery Passage (Dr. Dawson.)

\section{Velitina prolongata, Carpenter.}

Rept. Brit. Assoc., 18(t;, p. (6i) (August, 18(64); and Ann. Mag. Nat. Hist., series 3. vol. xv., p. 32. (.January, 1865).

This is a rare species. ('arjenter described it as rare in Swan's collection and since that time it has only been found in British Columlia by Dr. Newcombe, who took some very large specimens between tides at Victoria and who has found others at the roots of Macrorystis at ('layoquot Sounc.

$V$. prolongata has been found, according to Dr. Dall, both to the north and to the south of us, from Sitka to Monterey.

ACM EA, Eschscholtz.

298. ACM.EA patina, Eschscholtz.

Zool. Atlas, pt. 5, p. 19, pl. xxiv, tigs. 7, 8 (1833).

Those who wish information as to the rather extensive symonymy of this and other west coast limpets are referred to the papers of Drs. Carpenter ${ }^{1}$ and Dall ${ }^{2}$ in the American Joumal of Conchology ; of Dr. 1)all ${ }^{3}$ in the 'Proceedings of the United States National Museum,' and of 1)r. Pilsbry in volume xiii. of the Manual of Conchology.

1 "On the Acmiricle of the Vancouver and Californian province" Amer. Journ. (onch., vol. ii, pp. 333-348 (1866).

" "On the Limpets; with special reference to the species of the west coast of America, and to a more natural classification of the group." Amer. Joum. Conch., rol. vi., pp. 22-i-282, pl. xiv. to xvii. (1570).

"3 "Report on the Limpets and Chitons of the Alaskan and Arctic regions with descriptions of genera and species believed to be new." Proc. I. S. Yat. Mus., I. ㄴ. $281-344,5$ plates (1878). 
Dr. Dall unites A. patina with the Atlantic A. testudinalis. of Müller (Prodr. Zool. Diın.. p. 237, 1776), but Pilsbry. and with him I agree, considers that as the Pacitic shell is in nearly all its valliations readily distinguishable from its Atlantic antogue, thepe is no good purpose to be served by dropping our west coast name.

A. patina is extremely abundant in this province and very vitriable. I have collected and carefully studied many thousands of specimens and I : $m$ not even ret quite satistied that we are not now erring in uniting forms that are specifically distinet, as we erred before by indulging in excessive subdivisions.

A small deep water variety? of patina is no larger than and has somewhat the shape of A. virginea. A narrow and compressed variety occurring of leaves of Zostera at extreme low tide, seems to represent the Atlantic A alceus, Conral. Ciant specimens found between tide marks sometimes attain a length of nearly three inches.

In nearly all our Vanconver Island localitics two torms, very ditferent to each other, exist side by side. The one is large and flat with an open colour lattern, the other more conical, darker in colour and with the markings much more delicate and close. This last is evidently the A. scutum of Eschscholtz, and in some of its ratrieties can hardly be distinguished from the Chilian A. scutum of U'Orbigny. Near Victoria it is rare to tind a specimen that cannot at once be referred to the one or the other of these two forms.

Dr. Jeftreys (in a paper which I have reterred to under Modiolaria marmorata) speaks of this species ax being very common in lapan, where however I do not think it oceurs at all.

The valiety ochracea, Ditl, described from Monterey, is aredited to Vanconver Island by J)r. Pilsbry, lut I have never seen a native specimen.

\section{Acrla perta. Eschscholt\%.}

Zeol. Atlas, pt. 5, p. 19, no tigure (18;33).

+ 1. cussis, Esch, Zool. Atlas, pt. ., 1. 19, pl. xxiv, fig. : (1心33). etc., ete.

This species is almost as common as $A$. patina. It is very variable lut it does not approach the last named in any of its forms. In the adult shells the interior is often entirely white, but there is a curious valrety in which the interior is marked with numerous and close raised lines of purplish hown radiating from alpex to the alger.

300. Acm.ta persona, Fischacholt\%.

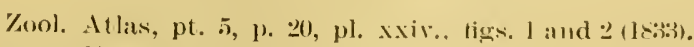

+ algitalis, Esch., etce, etc.

This is a smaller species than either $A$, patina or A. pelta, and is not quite so conmon. It is generally tound rerg near high-water marls. and consequently it must spend much of its time out of water. 
Californian specimens of $A$. persona are very difterent in appearance to Vancouver Island ones, and might at first sight be considered as belonging to a distincet species.

The nearest ally of $A$. persona is, to my mind, the Acmera dorsuosa, Gould, from Japan.

Dr. Pilsbry sees a resemblance to persona in the Chilian A. ceciliana, D'Orb., and has described an intermediate form as $A$. subpersona. I have never seen this last named shell, the tigure of which certainly does look like persona. but I have examined scores of A. ceciliana, and never saw one in the slightest degree approaching our $A$. persona. If Dr. Pilsbry's A. subpersona is really a Chilian form, I should certainly be inelined to give it specitic rauk.

\section{Acmilia instabilis. Gould, sp.}

Pretella instrbilis, Gould, Proc. Bost. Soc. Nat. Hist., vol. ii., p. 1.50 (July, 1846); and U. S. Expl. Exped., Mollusca, p. 346, figs. 454, 454 (1852).

This is not a common limpet, and it has so far been found living in British Columbia only on the west coast of Vancourer Island, where it occurs on the stems of Macrocystis.

$A$. instabılis has been considered by some conchologists to be only a kelp form of $A$. Felta, but Dr. Pilsbry with others (myself included) consider this by no means proren.

302. Aсм.ea mitra, Eschseholtz.

Zool. Atlas, pt. 5, p. 18. pl. xxiii.. tig. 4 (183:3).

Common at low ticle on all our coasts. Often coloured green or pink by encrusting nullipore.

Acmua scabra, Nuttall, common in California, has been quoted from Vanconver Island, but I have never seen a native specimen, and do not believe that it occurs here.

\section{CRYPTOBRANCHIA, Middendortti:}

\section{Cryptobranchia concentrica, Middendorfit.}

Pretelle rerece, var, roncentricr, Midd., Bull. Acad. Sici. St. Peters., vol. vi., no. 20, p. 319 (November, 1847).

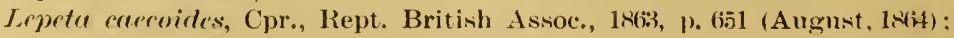
and Proc. Acad. Nat. Sci. Phila., 186.5, p. 60.

Not uncommon, attached to stones or dead shells dredged at Victoria, Departure Bay, Comox and Clayoquot. Also off Metlakatla in twenty fathoms, oft' False Head and in Quatsino Sound (Dr. Darson).

For notes on the anatomy of this species and its distribution, and 
for descriptions of nearly allied forms, see I)all (in Amer. Jonr. Conch., vol. v., p. 140 et ser.), "Materials for" a Monograjul of the Framily Lepretid:r."

LEI'TO'THYRA, Carpenter.

304. Leptothyra Carpenteri. Pilsbry.

= Leptothyra semyuinfa, Cpr., non linne.

Not common in the sonthern part of the province. I have taken it alive between tides at Vietoria, and so has Dr. Newcombe, and Proff. Maconn found it in a similar station at sooke.

Dr. Dawson dredged it in several Queen Charlotte Island localitien aud also in the Queen Charlotte and Quatsino Sounds. He also found it between tides in Johnston and Broughton Sitraits, in the fioletax Channel, and on the east side of (Queen Clandotte Sound.

It is very common in the little baskets of dead shells that the Indians from northern points bring to Victoria tor sale, but I do not know the exact locality whence these are obtained.

305. Leptothyra bacula, Carpenter.

Lrptonyx bacula, Cpr.. Rept. Brit. Assoe., 1863, p. 65:2 (Angnst, 1s64) : and Proc. Cal. Acad. Sci., vol, iii., 1 soió.

This little shell, which is not rare to the south of us, has not been found in British Columbia except by myself; and I have taken two specimens only, near Victoria.

\section{PACHYPOIS, Gray.}

306. Pachy pona in.equale, Martyn, sp.

Trochus imrepealis, Mart., Unir. Conch., vol. i., no :31, pI s, tign + (17ist).

$=T$. gibberosus, Chem. (1788).

This is a species which in British Columbia is confined to the north and west. It was reported by Dr. Dawson, "Common on rocks at low water" at the Queen Charlotte Islands ; and again, "On rorks and kelp at a little below low-water mark in Quatsino Sound. abundaut in some localities." It has been taken also on the west coast of 'Tancourer Liand by Dr. Newcombe and other's.

Very often groups of Bironia compacta are attached to sperimens of this shell.

The opercula of this species are commonly used by the Indians fiol oruamenting wooden and other wares.

In. Carpenter adopted Chemnitz name, being apparently not quite convinced that our shell was the one described and figured hy Martron and which was said to inlabit the Friendly Islands. 
CHLOROSTOMA, SWainsoll.

307. Chlorostoma fentibrate, 1. Milams.

Proc. Zont. Soc. I mondon, 1854, 1). 311i.

This species, like the last named, is contined to on1 nopthern and morthwesterin coatsts.

It is not uncommon, where it occurs. and is usually found living at, or just below. low-water mark.

D1: Dawson found it abundant between Nahwitti Bar and Quatsino Somnd. Professor Macoun collected many specimens at Alberni in 1887, amd [)r. Newcombe found it at ('layoquot Sound last year.

1) 1 . Newcombe in his catalogue eredits this species to the (2neen Charlotte Islands on the authority of Dr. Dawson, but I camnot find the record in any of Mr. Whiteares pajers on I)r. Dawsons collections.

FrlBBULA. 'Risso.

308. (imbula puligo, Martyu, sp.

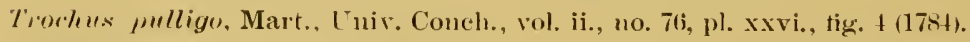

This is another west coast species with a distribution apparently similar to that of the last named. These shells are most frequently found on the fronds of Macrocystis pyrifera.

CALLIOSTOMA, Swainson.

309. Calliostoma annulatum, Martyo. sp.

Tireflue ammulutus, Mart., I'nir. Conch., vol. 1, no. 33, pl. x., tig. 2 (1784).

This species is not very common. Most of the specimens I have seen alre from Victoria where the speeies is dredged in shallow water: and sometimes, though rery rarely, is found above low-water mark.

Dr. Dawson found two specimens in Ilouston-Stewart Channel and a single small one in Forward Bay. I did not obtain this species in Departure Bay nor have I yet seen it from the west coast of lancourer Island.

\section{Calliostona canaliculatum, Martyn. sp.}

Tirorlues ronoliculatus, Martyu, Lniv. Conch., vol. i., no. :32, pl. x., tign. 1 (17ist).

This species appalrently belongs to the west coast of Vancouver Istand although it has been dredged near Victoria. on one occasion, by 1)1: Newrombe.

Dr. Neweombe has also taken it, alive. at Clayoquot found and Dr. 
Dawson obtained fumr specimens in Virago found. Like the uther west eoust Trochide this species appears to be partial to Macrocystis.

311. Caliostona Costaten. Martyon. sp.

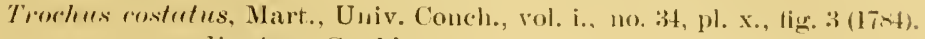
ligatum, Gould,

\&c., \&c.

This is our common Calliostoma and unlike the two species above mentioned is usually found between tides. The living shell very often has specimens of Crepidula adunca attached to it and when dead has nut unfrequently Crepidula nacicelloides within the aperture.

\section{Callostoma variegatu, Carpenter.}

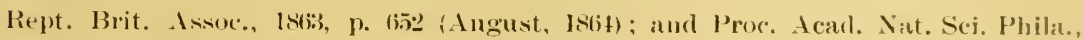
$18\left(i_{0}\right.$, p. 6 i.

Dr. Kennerley found one living specimen of this shell in Puget Sound, but I can find no other record of its occurrence in British Columbian waters.

\section{CANTHARIDUS, Montfort.}

313. Cantharides pupolnels, Carpenter, sir.

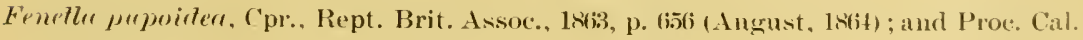
Acad. Sci., vol. iii. (1865).

This shell which Carpenter placed in Fenella, is considered by Dr. Dall to belong to the subgenus Halistylus (Dall) of the genus Cantharidus (Montfort). It was described from specimens taken near Monterey, C:alifornia, and was added to our list by Dr. Dawson, who took one adult living specimen at the mouth of Cumshewa Harbour in twenty fathoms.

Last summer Dr. Newcombe took four living specimens, and a few dead ones, at Clayoquot Soumd. We have not yet found it on the castern side of Tancouver Island.

\section{MARGIIITI, Leach.}

314. Margarita helteini. O. Fabricius, sp.

Trochess helirinus, O. Fab., Fanna Groenl., 1. 398, (1780).

Fine specimens, exactly like European ones, are common between tides in a few spots in the neighbourhood of Victoria, also at rooke (Macoun). A few specimens were taken by l). Dawson at the Queer. ('harlotte [slands. and in .Johnston Strait, and Queen ('hatrotte found. 


\section{Margarita Vahlit, Mäller.}

Index Moll. Groenl., p. \& (1842).

Three specimens, which Carpenter referred with doubt to this species. were collected by Dr. Kennerley in Puget Sound. I have not hearl of any other specimens being taken in our waters, the shell recorcled by Mr. Whiteaves under this name as having been collected by Mr. Richardson at Victoria. heing referable to Solariella varicosa.

316. Makgarita pupilla. Gould, sp.

Trochues puppillus, Gould, Proc. Bost. Soc. Nat. Hist., iii., ]). 91 (Mitrch, 1849). var. = inftatu, Cpr.

'This species is a rery abundant one with us. It is found both between tides and down to thirty or forty fathoms, the deep and shallow water forms being constantly distinet.

It occurs all through the province, being one of our commonest shells.

\section{Margarita lirulata, Carpenter.}

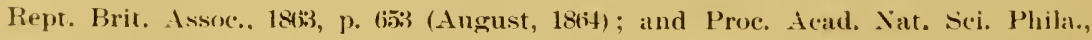
$186 \overline{5}$, p. 61 .

According to Dr. Mall the Margarita tenuisculpta of Carpenter and fire of the same author's species of Gibbulu, viz., obtabilis, parcipicta, funiculata, succincta and lacunata, are all forms of this very variable fpecies. Dr. Dall's opinion was based on the examination of very numerous specimens. In British Columbia $M$. lirulata is very abundant indeed on and under rocks between tides, the commonest form being one answering to the description of Gibbula succincta. Specimens dredged are usually of the more brightly coloured and bighly sculptured rarieties.

SOLARIELLA, Scarles Woods.

\section{Solarielda varicosa, Mighels and Adams, sp.}

Murguritu ru.ieuse, M. and Ad., Proc. Bost. Soe. Nat. Hist., vol. i., p. 4! (Noven1ber, 18t1); and Bost. Jomrn. Nat. Hist., vol. iv., no. 1, p. 46, pl. iv.. tig. 14 (.J:เnnary, 184:2).

= Troedus (Maryarita) I'ancoumensis, E. A. Smith, Ann. Mag. Nat. Hist.. series .j, vol, vi.. p. $288(1880)$.

This is not a very common shell with us, having only been met. with at Victoria and ofl Pender Island (Newcombe).

J). Dall was kind enough to compare my shells with Atlantic fpecimens and assures me that they exactly correspond. I hare myself 
compared specimens from Victoria with Mr. Smith's type of Vancowverensis, in the Natural History Musenm (South Konsington), and found them to agree in every particulat.

\section{Sol,ariblla peranabilis, Gapenter.}

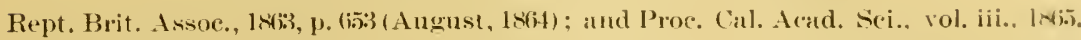

This rale shell was first tound at Catalina Island, California. ly Dr. Cooper. In our province six the living specimens were dredged by Dr. Dawson off False Head, Vancouver Is]and, in thirty fathoms. and one dead shell, in far condition. Was dredged by myself in Departure Bay in 1888 .

\section{:320. Solorariella cidaris, ('ilpenter, sp.}

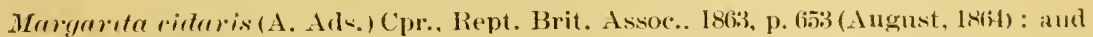
Ann, Mag. Nat. Hist., serics 3, rol. xiv., P. 126 (December, 1864).

Until 1885 this heantiful species was known only by the unique type specimens collected by Swan in Puget Sound. In that year Dr. Dawson dredged a splendid series of twenty-two specimens-in Forward Bay, (eighteen specimens) off False Ileal, (two specimens) and in quatsino Sound (two specimens).

This shell has since been obtained by the U.S. Fish Commissinn in San Pedro Bay.

- Mr. Whiteaves has a note on 1 his species and two excellent tigures of the langest of Dr. Dawson's sprecimens. in the "Uttawa Xaturalist "fin" December, 1893 (vol. vii., 1. 135).

H ALIOTIS, Limne.

\section{3:21. HaLiotis kamtschatkina, Jollas.}

Zeilschr. f. Mal., 1siñ, p. 1 lit

Not nncommon on boulders at low-water mark on our northern and northwestern coasts. The animal is used as food. by the Indians, and the shell for ormamental pur'poses. Dr. P'ilsbry in his "Manual "place- $H$. Kamtschatkana as a valliety of $H$. gigantea, Chemnitz (.Jaj)au).

PUXOTURELLA, R. T'. Lowe.

322. Puncturella cleglatat. (iould, sp.

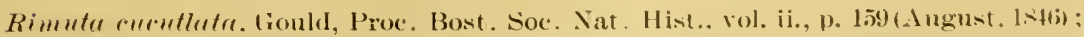

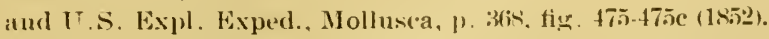

:32:3. Puncturkila galikata, (iould, sp.

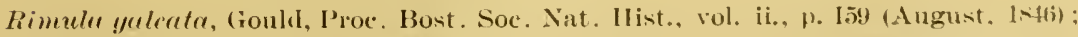

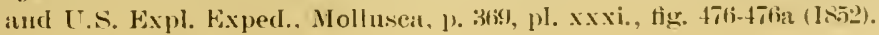




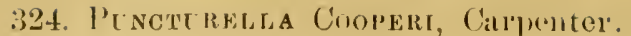

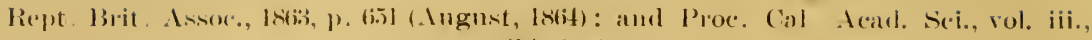
p. $21+\left(18\left(i_{0}\right)\right)$.

(If our thee sprecies of Puncturella the two tisit named seem to be fairly common and they are nsually drerlged attalcherl to stomes or dead sherls in ten to thirty or more fathoms.

$P$. cucullata ocenrs in two forms, which may possibly prove to be distinct-the one has few and rery prominent ribs while in the other the sculpture is closer and much finer.

$P$. rooperi is the smallest and rarent of the three. and so far has only been taken in this province, at Departure Bay, where I lledged it in 188S, aml again last year, in company with $P$. galeata.

Dr. Pilsbry mites the last named species with the Atlantic $P$. noachina, Linne, sp.

HALARIIT LLA, Tamarck.

325. Emarginula craisa, J. Nowerby.

Min. Concli., p. 73, pl. xxxiii, nppere fignres.

The occurrence on our coasts of this rare European shell was hardly - expected. The single specimen believed to have been talien at the Queen Charlotte Islands hy Dr. Datwson is thas recorded by Mr. Whiteaves in the "Ottawa Naturalist," vol. vii, p. 135: "An adult shell of this species with the animal, was found in a jar containing large specimens of Solaster Stimpsoni, Solaster Dausoni, Cribrella leviuscula and other starfishes chatracteristic of the British Columbian marine fanna, preserved in alcolol, the contents of which, except the alcohol, were stated by Dr. Dawson to have heen dredged hy him at the Queen (harlotte Islands in 1878."

\section{FISSC LIDEA, Siwainsol.}

3206. Fissurtiea ispera, Eschscholt\% sp.

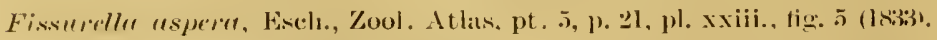

rertitir, (rould.

('ommon between tides from Victoria to the (2ucen Charlotte lskinds. I large percentage of the shells of this species are found to contain lesides the rightful inhabitant a parasitic annelid-Lepidonotus Lordi, Baird. Dr. Newcombe states in his " ('atalogue" that he has observed similar worms in the shells of Puncturella cucullata and Acmea mitra. 
MEGATEBENTES, P'ilsbry.

327. Megatebennus binacrtatus, Dall. sp.

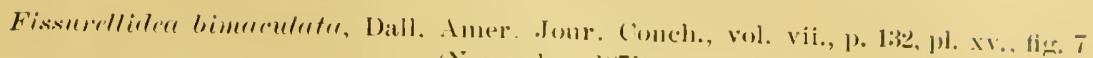
(Novemler, InTI).

This little shell seems to he rery late in British Cohmbia. Dr. Dawson dredged two dead specimens in Honston-stewart channel, (pueen Charlotte Islands: Dr. Newcombe found a few specimens living at the roots of Macrocystis in Clayoquot Socnd ; and I latre a single deal shell. which I ficked up on the beach at Vietoria.

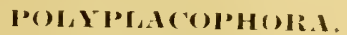

\section{CHITONID E.}

The Chitons of the Pacific coast are numerous and very interesting and as a consequence they have receivel a good deal of attention at the hands of conchologists. Drs. ('arjenter. Dall, and Pilsbry, have all written at length upon this subject and it will be sufficient for present purposes for me to refer to their papers and to limit my own remarks to a simple recold of the distribution of the various species within our province.

I may saly that while there are still some of the smaller forms about. which we are in lonbt the names of the majority of our Chitons are. I believe, correctly determined. Numerous specimens of all hut three $u t^{\circ}$ the specien admitter to this list are in my own collection.

\section{LFPIDOPLEURUS, Risso.}

\section{Lipidopletrus canchlaAtus. Sowerby sp.}

\section{Chiton remeellatus, shys, Conch. Ill., tigs. 104-105(1s:3!)}

This species is of common oceurrence under stones between tides and it has also been dredged not unfrequently neap Victoria and in Departure Bay, attached to stones and boken pieces of shell. It was also obtained in this way by 1h. Jatwon at Alert Bay and Freshwater Bay.

$L$. cancellatus resembles. very nearly, sereral other species of the same genus, amd I am not quite sure that all our lancourer specimens really belong to the present species.

1 The most importint ars:

Carpenter: Supplementary Report to the Britisl Association, locis.

Dall ; Report on the I impets and Chitons of the .tlaskal and Aretic regions, de. (See note mules - Lemuru patimu.)

Pilsbry ; Mammal of Conchology, vol, xiv.

The synomymy of ome species will be found exhanstively treated in llat two lant named works. 
TRACHYI)ERMON, Carpenter.

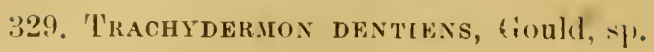

Chitem firutiens, Gould, Proc. Bost. Soc. Nat. Hist., rol. ii., p. 145 (.July, 1846); and

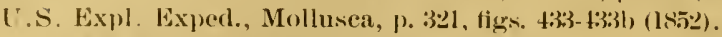

- Trachydermon preadodentions, C'pr.

I have a few specimens of this species foumd on rocks between tides meil. Victoria. The shell does not seem to have been reengnized by Mr. Whiteaves in Dr. Dawson's collections.

330. T'richydermon flectens, ('arpenter.

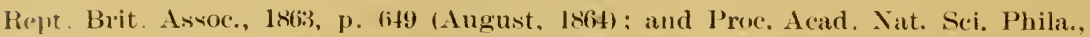
1865, p. 60.

A pretty little species collected liere by both Lord and Kennerley (toste Carpenter). I have taken it not rarely; by dredging, at Victoria and Departure Bay; but strangely enough Dr. Dawson did not obtain it during his northern trips, nor has Dr. Newcombe found it in any of the localities in which he has collected.

\section{TONICELLA. Carpenter.}

:31. Tonicella lineata, Wood, sp.

Chiton linentus, Wood, Gien. Conch., p. 15, pl. 2. figs. 4-5) (1815).

Tery common between tides on all our coasts. It is a very variable species but always readily separable from its allies. A pretty variety, of which I took two or three specimens at Nanaimo last year, is, when alive, wholly bright blue without any trace of the charateristic lineation. Dr. Pikbry calls this species "One of the hatudsomest north Pacitic ('bitons," and so it undoubtedly is.

3:32. Tonichila , subiakmonea, Middendorfí, sp.

('hiten submarmorrus, Midd., 13ull. Acarl. Sci. St. Peters., vol. iv., no. si(1E46); and Mal. Rusi., pt. 1, p. 4 , no. + (1siti).

Of this species only a few specimens have so far been taken at Vietoria, Departure Bay and Salt Spring Island (fi. W.T.) and Galiano Inland (Newcombe).

Carpenter placel $T$. submarnorea on our Vancouver list on the strength of specimens collected by Swan, but added a note "perhaps = lineata without the lines." It is however easily distinguished from lineata, as Pilsbry remarks, by its microscopic granulations, and from the following species, T. marmorea, by its different colour patterm. 
333. Tonicella marmorea, O. Fabricius, sp.

Chiton marmoreus, O. Fab., Fauna Groenl.. p. 420 (1780).

This is a species that I have searched for, so far, in vain. So far as I know it has only been taken in the Pacific Ocean, near the Aleutian Islands (Dall), anck at Japan, and by Dr. Dawson in Houston-Stewart Channel, Queen Charlotte Islands (two specimens).

It is a common species on both sides of the Atlantic Ocean.

CIANOPLAX, Pilsbry.

334. Cyanoplax Hartwegit, Carpenter, sp.

Chiton Hartwegii, Cpr., Proc. Zool. Soc. London, 185̃, p. 231.

335. Cyanoplax Nutwalli, Carpenter, sp.

Chiton Nuttallii, Cpr., Proc. Zool. Soc. London, 185̃5, p. 231.

C. Nuttallii is recorded from Paget Sound (Swan), and C. Hartwegii is said to have been found at the Queen Charlotte Islands by Dr. Dawson. Dr. Pilsbry supposes the two to be forms of one species. My own specimens of $C$. Hartwegii (I have not met with the other form) are from Victoria, but they are not any of them quite like the typical Californian ones. ${ }^{1}$

\section{ISCHNOCHITON, Gray.}

336. Ischnochiton interstinctus, Gould, sp.

Chiton interstinctus, Gould, U. S. Expl. Exped., Mollusca, p. 322, pl. xxvii., figs. $423-423 \mathrm{~b}$ (1852).

This beautiful little species is very common on stones and dead shells dredged in ten to thirty fathoms, at Victoria, Departure Bay and elsewhere. Dr. Dawson obtained it in Virago Sound and HoustonStewart Channel, Queen Charlotte Islands, and in many more southerly localities. Occasionally small specimens may be found under stones between tides.

\section{Ischnochiton Reteporosus, Carpenter, sp.}

Trachydcrmon retiporosus, Cpr., Rept. Brit. Assoc., 1863, p. 649 (August, 1864) ; and Proc. Acad. Nat. Sci. Phila., 1865, p. 59.

=Leptochiton punctatus, Whiteaves, Trans. Roy. Soc. Can., vol. iv., sect. iv., p. 125, figs. 3 and 4 (1886).

This is usually found in company with the last species and is

I Since the above was written, Dr. Pilsbry has described this form, which occurs also in California, as a distinct species under the name Trachydermon (Cyanoplax) Raymondi. Nautilus, vol. viii., p. 46 (August, 1894). 
equally abund:unt. It varies a good deal in colour, as does $I$. interstinctus also, but is usually much clarker than that species.

An exceptionally pale specimen was named Leptochiton punctatus, by Mr. Whiteaves, under the supposition that it was a new species.

ISCHNORADSIA, Shuttleworth.

338. Ischnoransta Mertensit, Middendorff, sp.

Chiton Mertensii, Midd., Bull. Acad. Sci. St. Peters., vol. vi., no. 8. p.118 (April, 1847); and Mal. Ross., pt. 1, p. 125, no. 16, pl. xiv., fig. 1-3 (1817).

This species is found, but not plentifully, in most localities examined from V.ictoria to the Queen Charlotte Islands.

It is most frequently obtained by dredging, but is sometimes found between tides. Some very large specimens were collected by myself on the roeks at low water at Salt Spring Island.

339. Iscirnoradsia trifida, Carpenter, sp.

Trachydermon trifichs, Cpr., Rept. Brit. Assoc., 1863, p. 649 (August, 1864); and Proc. Acad. Nat. Sci. Phila., 1865, p. 60.

The type specimen of this ratre species was collected by Dr. Kennerley in Puget Sound. Two specimens were obtained by Dr. Dawson, one at the month of Cumshewa Harbour in twenty-nine fathoms, and the other in Queen Charlotte Sound.

Quite lately Dr. Newcombe has found one or two specimens ncar Victoria. These are all the British Columbian specimens I have heard of, and to the north of us $I$. trifida is equally rare.

NUTTALLINA, Carpenter.

340. Nuttallina scabra, Reere, sp.

Chiton scabra, Reeve, Conch. Icon., Mon. Chitons, pl, xvii., fig. 106 (181i).

Dr. Kennerley is said to have collected one young living specimen in Puget Sound. Dall gives the distribution of the species as "Vancouver District, south to California, probably in the southern islands of Alaska; at and above high-water mark, in crevices of the rocks; at Monterey abundant."

I have seen numerous Californian specimens but have nerer found or seen a British Columbian example.

MOPALIA, Gray.

341. Mopalia cilitata, Sowerby, sp.

Chiton ciliatus, Sowerby, Conch. Ill., p. 79, 1838

= C. muscosus, Gould, Proc. Bost. Soc. Nat. Hist., rol. ii., p. 145 (July, 1816); and U. S. Expl. Exped., Mollusca, p. 313, fig. 436 (1852).

var. Hindsii, Gray, Proc. Zool. Soc. London, 1847, pp. 69 and 169. 
342. Mopalia lignosa, Gould, sp.

Chiton lignosus, Gould, Proc. Bost. Soc. Nat. Hist., vol. ii., p. 142 (July, 1816); + C. vespertinus, Gould.

343. Mopalia Wossnessenskit, Middendorff, sp.

Chiton Wossnessenskii, Midd., Bull. Acad. Sci. St. Peters., vol, vi., no. 8, p. 119 (April, 1847); and Mal. Ross., pt. 1, p. 101, no. 6, pl. xi., fig. 1-2 (1847).

These three forms are all extremely common on rocks between tide marks all through the province.

As found at Victoria and other localities that I have visited the three are always quite distinct. In fact judging only from specimens in my own collection, I should be inclined to admit at least one other form to specific rank.

Dr. Dall on the other hand after the examination of a multitude of specimens places lignosa under ciliata as a subspecies, thus reducing our Mopalias to two.

Typical $M$. ciliata were not observed by me at Nanaimo last year, although lignosa and Wossnessenskii were very numerous; usually ciliata is the commonest form.

M. Wossnessenskii is very variable in colour ranging from brown to bright red or still brighter emerald green.

\section{PLACIPHORELLA, Carpenter.}

Dall suggests (Proc. U.S. Nat. Mus., 1886, p. 210) that Placiphorella be retained for the group of $P$. velata, Cpr., and a new subgenus of Osteochiton be formed for $P$. sinuata and $P$. imporcata, but for the present we include our three species under the one generie title.

\section{Plaorphorella veiata, Carpenter.}

Not rare in California but only known as British Columbian from one fine specimen found last summer by Professor Maeoun, on the roeks at Sooke Harbour, Vancouver Island.

\section{Placiphorella sinuata, Carpenter.}

Mopalia sinuata, Cpr., Rept. Brit. Assoc., 1863, p. 648 (August, 1864); and Proc. Acad. Nat. Sci. Phila., 1865̃, p. 59.

346. Placiphorella imporcata, Carpenter.

Mopalia imporcata, Cpr., Rept. Brit. Assoc., 1863, p. 648 (August, 1864); and Proc. Acad. Nat. Sci. Phila., 1865, p. 59.

Neither of the above species are common. 'The former oceurs at Victoria in ten to thirty fathoms, and has also been taken by me in some numbers on rocks at low tide in Departure Bay. $P$. imporcata 
occurs with sinuata at Victoria and has been dredged at Ganges Harbour and Comox by Dr. Newcombe, and in Forward Bay (a single specimen) by Dr. Dawson.

\author{
KATHERINA, Gray. \\ 347. Kiatherina tunicata, Wood, sp. \\ Chiton tunicatus, Wood, Gen. Conch., pl. ii., fig. 1 (1815).
}

This is a most abundant chiton on nearly all parts of our coasts. It occurs on the rocks between tides and is collected for food by the Indians and is occasionally seen exposed for sale in the Victoria fish stores.

The only locality in which I have failed so far to find $K$. tunicata, is Nanaimo. During four days collecting there last July, neither Professor Macoun or myself observed a single specimen; M. ciliata, as above noted, was also absent.

\title{
CRYPTOCHITON, Middendorff.
}

348. Cryptochiton Stelleri, Middendorff.

Chiton Stelleri, Midd., Bull. Acad. Sci. St. Peters., vol. vi., no. 8, p. 116 (April, 1847);

Mal. Ross., pt. 1, p. 37, 93, no. 1, pl. i. to ix. (1847).

This king among chitons is not uncommon in British Columbia, though by no means so plentiful as some others of our species.

It is usually found in the early spring upon the rocks at low water. A large specimen will measure nearly twolve inches in length.

\section{CEPHALOPODA.}

OCTOPUS, Lamarck.

349. Octopus punctatus, Gabb.

Proc. Cal. Acad. Nat. Sci., 1862, p. 170.

Carpenter records this species, with a query, as having been collected in Puget Sound by Kennerley, and in the same neighbourhood by Swan, and I suppose that we are correct in applying the name to the large Octopus that abounds near Victoria and which is, with the Indians, a much esteemed article of food.

\section{ONYCHOTEUTHIS, Lichtenstein .}

350. ONтсHотеUthis Fusiformis, Gabb.

Proc. Cal. Acad. Nat. Sci, 1862, p. 171.

This like the last species is given by Dr. Carpenter, with a query, as from Puget Sound (Kennerley), and I have a single specimen, which 
I suppose to belong to this spccies, and which I found in a dying condition on the beach at Oak Bay near Victoria.

\section{OMMASTREPHES, D'Orbigny.}

\section{Ommastrephes sagittatus, Lamarck, sp.}

This appears to be the commonest of our Cephalopods. It was first recorded from our province by Mr. Whiteaves who writes that three specimens were taken at low water in Victoria Harbour by Dr. Dawson. There are numerous fine specimens from varions British Columbian localities in the Provincial Museum at Victoria.

Of the species above enumerated, the following are of economic importance, being used as food by the Indians, and also, to a less extent, by the Chinese and whites. Most of them, in their proper season, may be seen exposed for sale in the Victoria stores:

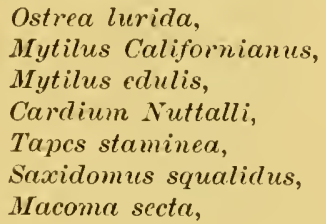
Octopus punctatus.
Macoma nasuta, Mecoma inquinata, Tresus Nuttalli, Mya arenaria, Haliotis Kamtschatkana, Katherina tunicata, Cryptochiton Stelleri,

Ostrœa Virginica is largely imported, but native specimens of this species are much too scarce to be of commercial value.

Many other of our species are edible, and in other countries would be sought after for food, but their value does not seem to have been discovered as yet by the British Columbians.

The larger Pectens (which I know from personal experience to be exceedingly toothsome, Penitella penita, Siliqua patula, Zirphoea crispata, the Purpuree, the Littorince and the Limpets, will possibly all some day be utilized.

A large number of our British Columbian Mollusca occur also on the "Old Country" coasts.

* Hemithyris psittacea,

* Limatula subauriculata,

* Mylilus edulis,

* Moctiola moctiola,

* Modiolaria nigra, Modiolaria marmorata,

* Crenella decussata,

* Nucula tenuis,
* Leda minuta, Kellia suborbicularis, Lasca rubra, Cryptoclon flcxuosus,

* Mya truncata,

* Mya arenaria,

* Saxicara rugosa,

* Panopaea Norregica, 
* Zirphaca crispata,

* Xlyophaga clrosalis, Xylotrya bipinnata, Tylotrya fimbriata, Cylichna cylindracca,

* Diaphana pellucida, Haminea hydatis, Bela Trevclyana,
Triforis adversa, Cerithiopsis tubercularis,

* Lacuna vincta,

* Ielutina laevigata,

* Margarita helicina, Emarginula crassa, Lepidopleur"us cancellatus,

* Tonicella marmorea.

Many of our land and freshwater shells are also common to the two continents, and a few species, *Macoma lata, *Natica clausa, *Admete Couthouyi, are found in England in a subfossil condition, though still living in our waters.

The foregoing list may be lengthened if we admit the following identifications :--

BRITISH COLUMBIAN.

Terebratulina unguicula, Lucina acutilineata, Dentalium indianorum, Bela fidicula, Purpura crispata, Eulima micans,

Eulima, sp., Trichotropis cancellata, Littorina sitkana, Acmera patina, Puncturella galeata.
BRITISH.

$T$. caput-serpentis,

L. borealis,

D. entale,

* B. turricula,

* P. lapillus, E. polita, E. distorta,

* T. borealis,

* L. rudis,

* A. testudinalis,

* P. Noachina.

The twenty-eight species in the foregoing lists that are marked with asterisks, and the following fifteen species, are known to occur also on the Atlantic coast of Canada :-

\section{Ostrea Virginica}

Modiolaria laevigata,

Yoldia thracicformis,

Yoldia limatula,

Astarte undata,

Serripes Groenlandicus,

Venericardia borealis (= ? ventricosa),

Bela exarata,
Bela violacea,

Buccinum cyaneum,

Chrysodomus liratus,

Trophon clathratus (=? multicostatus), Mesalia reticulata,

Alvania castunca,

Solariella varicosa. 



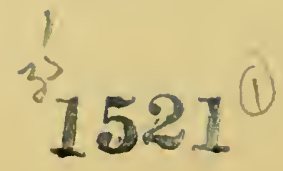





SMITHSONIAN INSTITUTION LIBRARIES

|| || | || || || ||

$3908800048 \quad 6498$ 